Review

\title{
Innovative Human Three-Dimensional Tissue-Engineered Models as an Alternative to Animal Testing
}

\author{
Patrick Bédard ${ }^{1,2}$, Sara Gauvin ${ }^{1,2}$, Karel Ferland ${ }^{1,2}$, Christophe Caneparo ${ }^{2}$, Ève Pellerin ${ }^{2}$, \\ Stéphane Chabaud ${ }^{2}$ (I) and Stéphane Bolduc ${ }^{2,3, *}$ \\ 1 Faculté de Médecine, Sciences Biomédicales, Université Laval, Québec, QC G1V 0A6, Canada; \\ patrick.bedard.2@ulaval.ca (P.B.); sara.gauvin.1@ulaval.ca (S.G.); karel.ferland.1@ulaval.ca (K.F.) \\ 2 Centre de Recherche en Organogénèse Expérimentale de l'Université Laval/LOEX, Centre de Recherche du \\ CHU de Québec-Université Laval, Axe Médecine Régénératrice, Québec, QC G1J 1Z4, Canada; \\ christophe.caneparo.1@ulaval.ca (C.C.); eve.pellerin.1@ulaval.ca (È.P.); \\ stephane.chabaud@crchudequebec.ulaval.ca (S.C.) \\ 3 Département de Chirurgie, Faculté de Médecine, Université Laval, Québec, QC G1V 0A6, Canada \\ * Correspondence: stephane.bolduc@fmed.ulaval.ca
}

Received: 8 August 2020; Accepted: 15 September 2020; Published: 17 September 2020

\begin{abstract}
Animal testing has long been used in science to study complex biological phenomena that cannot be investigated using two-dimensional cell cultures in plastic dishes. With time, it appeared that more differences could exist between animal models and even more when translated to human patients. Innovative models became essential to develop more accurate knowledge. Tissue engineering provides some of those models, but it mostly relies on the use of prefabricated scaffolds on which cells are seeded. The self-assembly protocol has recently produced organ-specific human-derived three-dimensional models without the need for exogenous material. This strategy will help to achieve the $3 \mathrm{R}$ principles.
\end{abstract}

Keywords: tissue engineering; scaffold; extracellular matrix; epithelium

\section{Introduction}

\subsection{A Brief History of Animals as Models in Science}

Scientists have used animal models in research at least since the Ancient Greek Era. For example, Alcmaeon of Croton studied the brain with dogs in the 6th century B.C. [1]. Since then, many different models have been used for different applications: the nematode Caenorhabditis elegans, the fly Drosophila melanogaster, zebrafish, frog Xenopus, mouse, rat, rabbit, dog, and primate rhesus macaque are some examples of models that have been used and which are still used today in research [2-6] (Figure 1). 


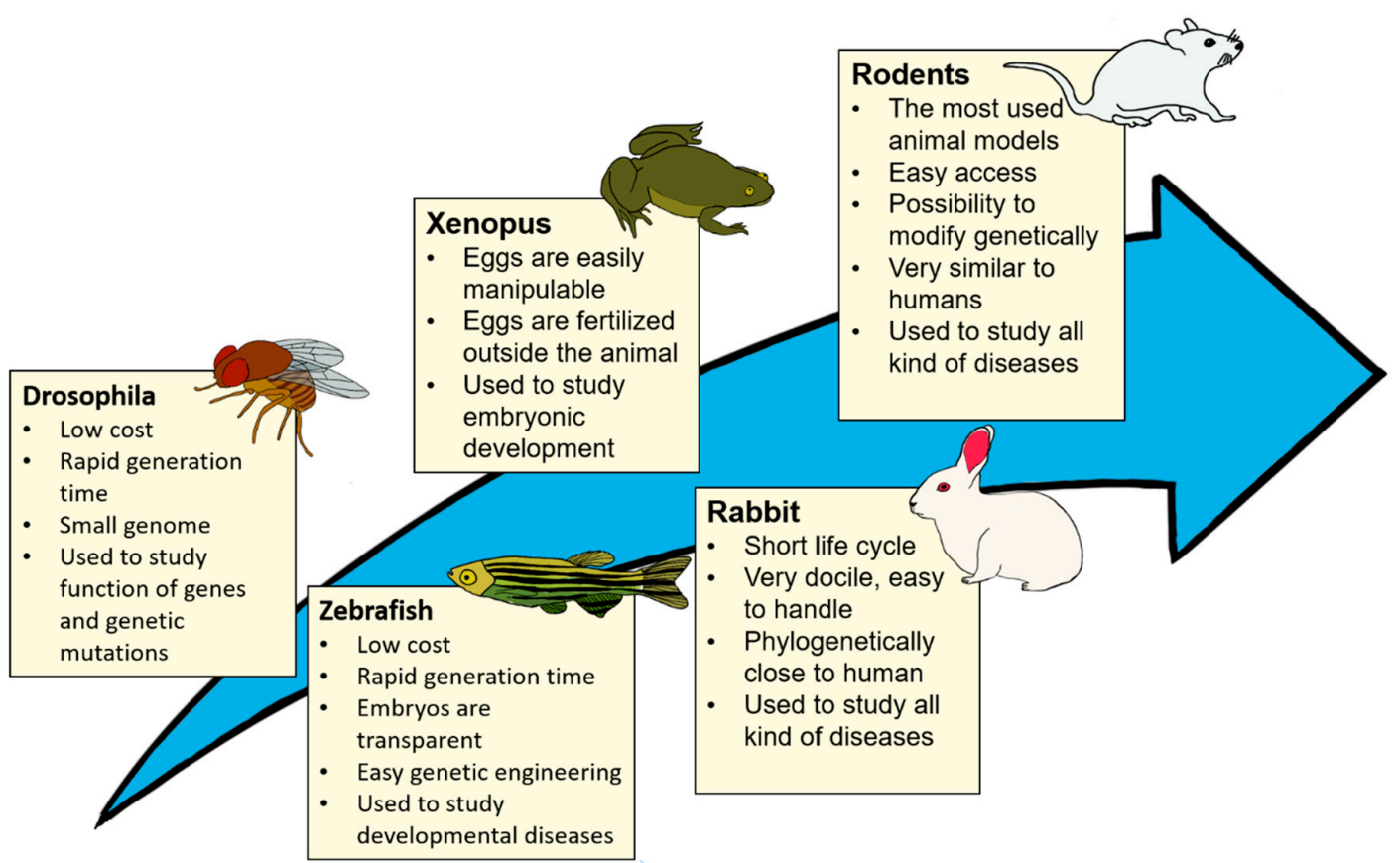

Figure 1. Advantages and applications of common animal models: drosophila [7], zebrafish [8], Xenopus [9], rabbit [10], or rodent [11] models in biomedical research.

The mouse and the rat are, by far, the most used animals (Figure 2). Animal models have improved in the past few years, and these modified animals now present more accurate models to medical research. For example, scientists can modulate animal genomes by adding or deleting genes to mimic disease or to study the function of these genes [12]. These animals are called transgenic animals. The most common transgenic animal is the transgenic mouse, but this technology applies to other species like rats, cats, and rabbits [1,13-16].

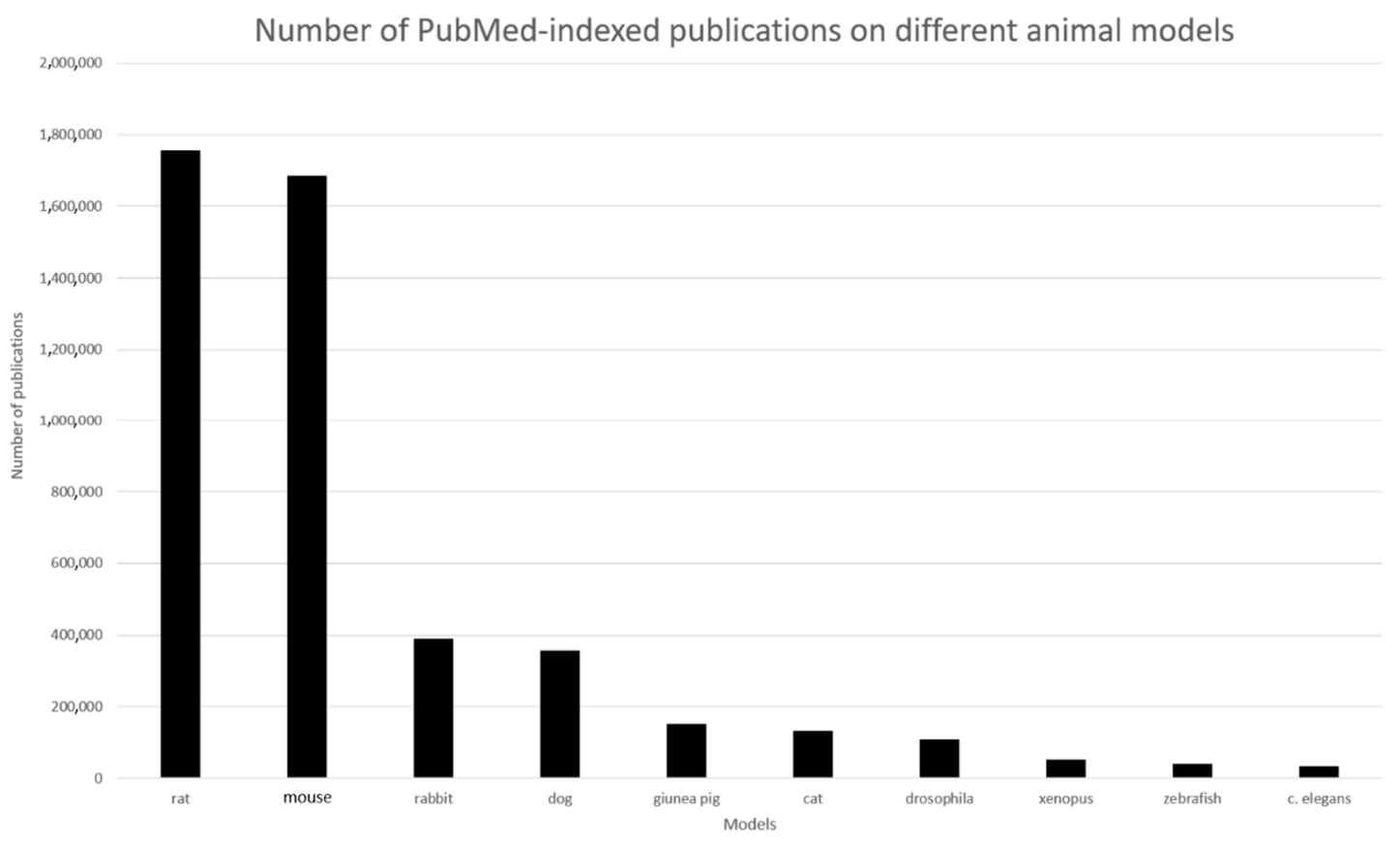

Figure 2. Number of Pubmed indexed publications on different animal models. The number of publications is the number obtained when entering the keyword in the search bar on PubMed website. 


\subsection{Why Animal Testing}

There are many reasons why scientists all over the world still use animals to study human diseases. First, non-human animals share genetic and physiologic similarity to humans. For example, mice share $80 \%$ of their genome with humans [17]. Since animals are very similar to humans, they can suffer diseases similar to human ones. For example, Joseph von Mering and Oskar Minowski have used a dog pancreas to prove that the pancreas has a role in diabetes [18]. Another advantage of an animal models is that while they often have a shorter life expectancy than humans, they generally share a similar ageing pattern; therefore, scientists can study disease in a lifetime in less time than in a human body [13]. Moreover, some pathologies or biological phenomena, requiring interaction between several organs, do require the use of animals as an experimental "unit": for example, studying metastases. In addition, despite the intense work of lobbying from opponents to animal testing, many regulatory agencies still require the use of animals in preclinical testing phases. For example, U.S. federal laws require that non-human animal research occur to show the safety and efficacy of new treatments before any human research will be conducted (U.S. Food and Drug Administration. Investigational New Drug (IND) Application. U.S. Food and Drug Administration. 5 October 2017. Available at the US Food and Drug Administration website.

\subsection{Relevance of $3 R$ Principles in Research}

If animal models can be seen as valuable tools to study human diseases, they nevertheless have several flaws. For example, more ethical concerns have been raised about the use of living things in research. In 1959, Russel and Burch defined the 3R principles for animal use in research: replacement, reduction, and refinement. To offer better treatment to laboratory animals, 3Rs were proposed in "the principle of human experiment technique" [19]. Replacing should be the primary goal of the 3Rs: if the research no longer uses animals, the problem related to their use disappears. Nevertheless, as this seems unrealistic in the short or medium term, reducing and refining should be short/middle-term goals. The term "reduce" means minimization of the number of animals that are used in research and the term "refine" corresponds to the use of techniques that are doing less harm to animals [20].

\subsection{Why Replacing, Reducing, and Refining?}

\subsubsection{Replacement}

In several cases, animal models should be replaced by more accurate and innovative in vitro models. First, there are many ethical concerns about animal use in research [21].

Moreover, the translation of results obtained from animal models to humans has long been questioned. In some cases, results observed in animals do not accurately predict human responses, like it has been the case for different toxicity tests that did not succeed in accurately predicting toxicity in humans [22]. The complexity of whole mammal organisms is also an aspect to consider [23]. Although animal models have been improved over time, for instance, to study specific conditions, there are still uncontrollable variables in animal organisms [24]. The reproducibility of research involving animal models has also been considered inferior, especially in preclinical research [25]. Because of the possible lack of relevant animal testing results, this practice has been qualified wasteful by some [26,27]. For example, the chimpanzee was considered an excellent model to develop a human immunodeficiency virus (HIV) vaccine in the 1990s. Some vaccines were promising in the primate, but the results were not the same in human trials. Indeed, the chimpanzee does not have the same immune system as humans. Still today, no vaccine has been found to prevent HIV [28]. The mouse model for cancer study is another example of the lack of accuracy of animal models. Many studies have described an elegant cure to treat cancer in mice, but very few of these results are translatable to humans [29].

Economic considerations also encourage the need for a change toward alternative in vitro models. The cost of animal breeding/housing for scientific purposes reveals high expenses and is an essential 
factor to consider [30,31]. In addition, animal protocols can be time-consuming and require skilled and trained operators to perform specific experiments [32].

The replacement of animal testing in research can be achieved through various alternatives [31]. These can sometimes bring entirely new information that cannot be obtained from studying animals, hence the importance of improving animal testing alternatives.

\subsubsection{Reduction}

In 2018, 780,070 animals were used for animal research in the United States [10]. This number excludes many species like mice and rats, which are not protected by the animal welfare act. The animal welfare act does not protect ninety-three percent of animals used in research; the estimation of actual animal use in research in 2018 is between 11 and 23 million. This is a slight increase compared to 2017; nevertheless, the number of animals used in research has been reduced by more than half since 1985 [10].

Various reasons led the industry to reduce animal testing: not only the ethical concerns related to the pain and distress animals can experience during protocols [33] but also the possible drawbacks of these models. Once again, saving experimental animal numbers is saving money.

The need to reduce animal testing has also arisen through legislations requiring adherence to the 3Rs. Since 2006, the EU Registration, Authorization, and Restriction of Chemicals (REACH) legislation has addressed animal testing. It aims to reduce the number of animal tests to a minimum while promoting alternatives [34]. Currently, several in vitro protocols, including tissue engineering-derived ones, have been designed to reduce animal use, especially for toxicological testing. For example, protocols using 3D reconstructed human cornea-like epithelium and epidermis models were set up as an alternative to in vivo Draize rabbit eye and skin irritation tests [35]. Several alternatives will be described in Section 1.5.

\subsubsection{Refinement}

Refinement is a crucial topic in research using animal models to improve animal welfare. Animals can feel pain and mental distress. For example, in 2010, a research team correlated the level of pain that mice were experiencing with their facial expressions in order to provide quantifiable data [36]. Providing a better quality of life to animals is especially important because animals' discomfort and distress during experiments can lead to fluctuations in the results and require repetition of these experiences, then increasing the number of animals. Briefly, the objective is, not exhaustively, to optimize the methodology applied to animals; this involves reducing, eliminating, or relieving their pain or distress, and thereby improving their wellbeing: to improve transport, breeding, and housing conditions, to plan the protocol to avoid stress, to use painless or non-invasive procedures, to provide adequate care before, during, and after the operation, to balance anesthesia procedures with regard to pain relief, to minimize the duration of certain studies to the strictly required period, and to choose more appropriate euthanasia procedures. The analyses should be carefully planned to obtain the maximum amount of data from the experiments.

However, this could not be directly modified by the use of tissue engineering (TE), which is the present subject. Many good reviews treat this subject $[37,38]$.

\subsection{Alternatives to Animal Models}

\subsubsection{Mammalian Cell Culture}

Cell culture is a promising approach to complement animal data or completely substitute it [31]. In these systems, cells originating from animal or human biopsies are grown in an artificial environment and are subjected to controlled conditions, including parameters such as $\mathrm{pH}$, osmolarity, temperature, humidity, and gaseous atmosphere. A culture medium is used to provide cells with nutrients (amino acids, vitamins, inorganic salts, and carbohydrates). However, it is generally further supplemented with proteins obtained from animal-derived serum as a source of growth factors and 
hormones [39]. Cell culture represents an indispensable tool to improve our understanding of cell biology and in vivo cell behaviour mechanisms. It is making rapid progress and its development has the potential to lead to a decrease in animal use [31]. Different cell culture techniques, including 2D and 3D methods, have been developed (see below). This follows a trend towards the development of models that better mimic the cellular microenvironment.

\subsubsection{Plant Tissue-Based Materials}

Toxicity assays in plants can be used for preliminary in vitro studies as a substitute for animals. While it is more complex to relate plant-based data to human research, different assays have been useful for safety assessment. For example, the Allium genotoxicity test has been useful for the screening of pesticides, water pollutants, or industrial waste chemicals [40]. Likewise, tests using pollen suspensions (pollen tube growth tests) have been reliable in some instances. For example, this test has been used to assess the safety of different mouthwashes [41]. However, plant substitutions' applications and success stay limited [42].

\subsubsection{Yeasts-Based Assays}

Yeast Saccharomyces cerevisiae has been used for the screening of potential genotoxic substances for over 40 years, thus contributing to reducing the large number of animals used in genotoxicity tests. Chemicals from anticancer drugs and pharmaceuticals, cosmetics, and insecticide residues are quickly and efficiently screened to detect any mutagens. Despite their limited capabilities, tests held on this unicellular eukaryote are being upgraded continuously, for example, by increasing the permeability of yeast cell walls [43].

\subsubsection{In Silico Methods}

Databases, computational models, or simulations are being actively developed to improve advances in medicine. Software can be used to help make decisions, predictions, and hypotheses. This way, it is possible to replace or reduce the use of in vivo tests by minimizing the need to test directly on animals. In pharmacology, in silico methods have been highly used for toxicology tests and drug screening. This allows high throughput screening and reduces time and cost in drug discovery [44]. With their rapid development, in silico technologies are considered to have a bright future [45].

\subsubsection{Other Methods}

Other alternatives, such as reconstructed enzyme systems [31], microbiological systems (from bacteria or fungi), DNA chips, or microfluidic chips [42] are being used, but they will not be further discussed in this text, as we focus on providing an overview of cell culture techniques and the relevance of their development as an alternative to animal testing in agreement with the $3 \mathrm{R}$ principles.

\subsection{Cell Culture}

\subsubsection{Two-Dimensional (2D) Cell Cultures}

Traditional 2D cell cultures have been used as in vitro models for over a century [46]. In these systems, cells are grown as a pure monolayer directly on plastic or glass flat dishes. The cells are in contact with a nutrient fluidic medium that can be modified to study various parameters. The simplicity and efficiency of 2D platforms have contributed to their general acceptance by the scientific community, and they are now a well-established practice [47]. For instance, they offer a relatively easy method to investigate cell behaviour via imaging or gene expression profiling. Their efficiency allows for high throughput screening (HTS) in drug discovery [48], which offers the potential to reduce animal use [31]. With these advantages, 2D models seem to represent an exciting method to replace animal testing. However, the limitations of 2D platforms have been highlighted throughout the years. The main limitation of these models is that they do not accurately mimic the natural 3D organization of cells 
and their extracellular matrix (ECM), thus varying the cells' microenvironment from the one found in vivo [49-51]. Consequently, cell-cell and cell-ECM interactions are not as representative as in vivo. Since cell behaviour, like cell differentiation, migration, morphogenesis, and proliferation, has been proven to be highly influenced by its biochemical and biomechanical microenvironments [47], 2D cell culture can lead to results that deviate from in vivo responses [52,53].

Various factors are responsible for the lack of accuracy between 2D and in vivo microenvironments.

The homogenous concentration of nutrients: As monolayers, cells obtain similar access to nutrients and growth factors from the medium. However, in vivo, the concentration of soluble factors that affect cell differentiation, migration, and communication is distributed through dynamic spatial gradients [54]. While this characteristic can make 2D cell culture an advantage for some research works, it does not allow for an accurate representation of in vivo conditions.

Substrates' rigidity: In 2D models, cells are grown directly on plastic or glass supports, which are rigid and stiff platforms. This does not allow for natural growth kinetics and cell attachments [49].

Planar environment: Growing cells directly on flat surfaces is unnatural and affects cell behaviour in various ways. Firstly, it promotes an artificial polarity between the apical and basal surfaces of cells [49]. This is mainly a problem when growing physiologically non-polar cells. A planar environment also restricts the development of complex morphologies that can usually deploy in a 3D environment. The migration of cells is also impacted because the lack of ECM causes a decrease in the resistance to migration.

Use of animal serum: Even if it is not specific of 2D cell cultures (it is also found in several 3D cell culture models), the use of animal serum, especially fetal serum, can induce cell reactions, which differ from the in vivo physiology. For example, it can mask several signaling pathways by activating other pathways. Moreover, animal serum contains not only cytokines and hormones but also the remainder of the extracellular matrix, bioactive lipids, etc., depending on how the serum had been prepared: the composition of animal serum can differ from lot to lot and provide inconsistent results. All these aspects will be discussed later in the text.

These deviations of the 2D microenvironment from the in vivo one lead to various problems. Misleading and non-predictive data for in vivo responses coming from 2D models are causing failure of clinical trials, which are expensive phases of drug development [53]. In addition, some essential characteristics of cancer cells cannot be appropriately modeled in 2D platforms because of their lack of efficiency to mimic physiological cell behaviours like migration [55]. Therefore, to accurately study various cell behaviours in vitro, 2D systems should be improved to models that replicate 3D in vivo organization to achieve a better imitation of the biochemical and biomechanical properties of the ECM. The more accurate the model is to the natural microenvironment, the more it could be relevant to replace animal testing.

The search for new culture platforms to improve physiologically relevant microenvironments in cell culture to solve these problems led to the development of so-called 2.5D systems that are considered midway between 2D and 3D cultures. There are different opinions on what consists of a $2.5 \mathrm{D}$ system $[56,57]$. However, Zerda et al. and Shamir et al. define $2.5 \mathrm{D}$ culture as growing cells on either biological or synthetic coating instead of directly on the plastic. Materials used as a coating represent the ECM and usually have topographical features, unlike plastic. This impacts the architecture of cells by modifying the cell membrane curvature, especially on the basal surface. A more physiologically relevant architecture of the tissue is developed that way [51]. Therefore, 2.5D models differ from 2D models by inducing curvature on basal cell surfaces, whereas basal surfaces of cells grown on 2D plastic surfaces are usually flat. However, it cannot be considered a 3D system as cells are not entirely embedded in the ECM and bear fluid facing surfaces, while this would not be the case in vivo. This results in an apical and basal polarity of cells and the modification of cell interactions by diluting cell-produced factors in the fluid [51], just like for 2D. While 2.5D models better replicate some features found in vivo than 2D classical models, they still face limitations in their representation of the natural microenvironment. 


\subsubsection{Three-Dimensional (3D) Cell Cultures}

Three-dimensional cell culture represents an excellent alternative to the animal model. A 3D cell culture is defined by a cell culture that can mimic a living organ's organization and microarchitecture [58]. Many methods have been developed in the last two decades to obtain 3D cell cultures (Figure 3). These methods will be presented further. The 3D cell culture market is expanding every year; it is projected to reach 1846 million USD in 2024 [58]. Every year, techniques improve; scientists can now make skin, cornea, blood vessels, and many more with 3D cell culture [59-61].

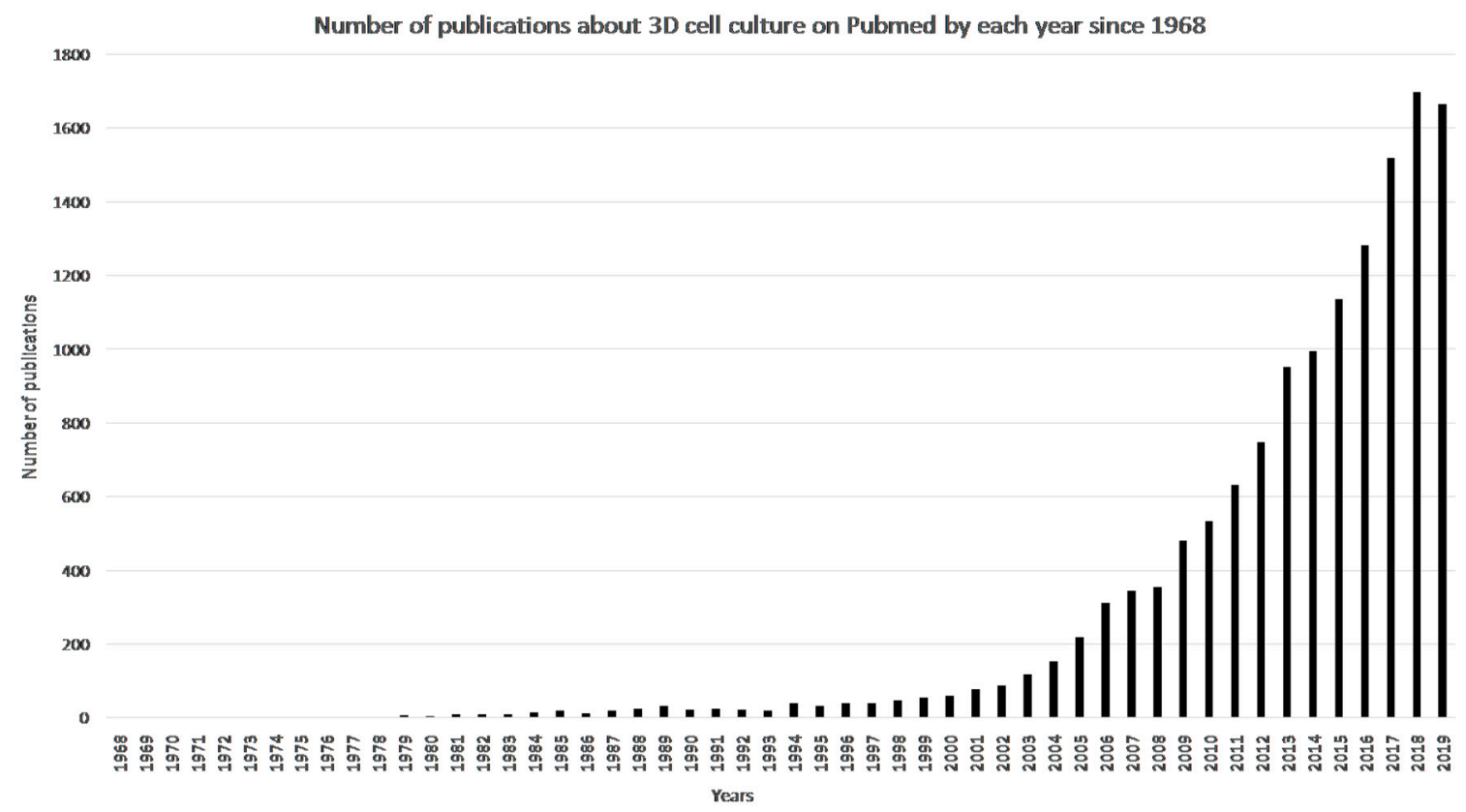

Figure 3. Number of publications per year about 3D cell culture on Pubmed since 1968. The number of publications is the number obtained when entering the keyword "3D cell cultures" in the search bar and applying the filter of results by year on Pubmed website.

\subsubsection{Advantages of 3D Cell Culture Compared to 2D}

The improvement of classical 2D cell culture to 3D systems offers an increasing opportunity to replace animal models. While 2D models could lead to misleading results and non-predictive data for in vivo responses because of their lack of accuracy to mimic an in vivo microenvironment [53], 3D cell culture succeeds to replicate a higher number of in vivo features [50].

With its three-dimensional organization, this method overcomes various disadvantages encountered in 2D-cultured cell microenvironments. Factors improved by a three-dimensional environment, where cells are surrounded by ECM, include heterogeneous access to soluble factors, nutrients, and oxygen [54,62], a more in vivo-like generation of apical-basal polarity [49], and better replication of mechanical stress by growing in a less stiff environment [49]. This allows for more relevant cell-cell and cell-ECM interactions [50] and contributes to making 3D-cultured cell behaviour more reflective of in vivo cellular responses. Overall, it has been found that these systems can promote better replication of cell morphology [63] and adhesion [49]. They can also enhance cell differentiation, proliferation, and migration [63] in addition to impacting cell survival [64] and gene expression [52]. This might enhance tissue-specific functions in 3D platforms.

Three-dimensional systems can be used to mimic more accurately specific disease models [65-68]. For instance, cancer models cannot be modeled with 2D classical cell culture as this method fails to accurately replicate essential characteristics of the tumour microenvironment like its dynamic and complexity. In a study by Karlsson and collaborators, 3D systems showed better resistance to 
anticancer drugs than in monolayer cultured cells, showing that results are profoundly impacted by a three-plane environment [69].

Therefore, although 2D models have contributed to highly increase our general understanding of cell behaviour, 3D cell culture can provide platforms that better replicate the in vivo environment for more reliable and predictable results for human application. Three-dimensional platforms are suitable for a wide range of applications, and numerous $3 \mathrm{D}$ cell culture techniques are being actively developed. This point goes in agreement with the $3 R$ principles, which aim to replace and reduce animal use.

\subsubsection{Advantages of Cell Culture Compared to Animal Models}

Besides sparing animal use and leading the way for a more human approach for testing, in vitro cell cultures have additional advantages that are not met when using animal models. Cell culture allows for better control of variables, whereas in vivo, many variables are uncontrolled, and their effects are sometimes unknown due to the complexity of organisms [23]. Thus, cell culture can enhance reproducibility and facilitate the study of cellular and molecular mechanisms [70,71].

An essential advantage of cell culture as an alternative to animal models is that human-based models can be grown by using human cells, thus possibly minimizing the questionable translation of in vitro results to humans. Furthermore, this opens the door for personalized medicine development. Autologous patients' cells can be grown for drug testing [72], disease modeling [65,73-75], and could even be useful to assess diagnoses [66]. Tissue engineering can also provide autologous tissues for patients in need of grafts for surgical reconstruction. Because of high risk of immunologic rejection and public health risk concerns, animal tissue transplant in humans is greatly limited [76,77]. Cell culture overcomes many graft limitations, like the lack of healthy tissue from a donor site, by allowing the growth of autologous and physiologically relevant tissues for grafts [78,79].

However, cell culture cannot wholly substitute animal use. Whole organisms are necessary to explore interactions between organs and physiological functions. This explains the recent emergence and improvement of 3D cell culture techniques to achieve the development of more complete and accurate in vitro systems following the objective of minimizing animal testing.

\subsubsection{Disadvantages of 3D Cell Culture Systems as a Preclinical Models}

Three-dimensional cell cultures offer an exciting substitute for animal use in agreement with the 3R principles. However, its improvement faces different challenges and its use can be limited because of certain drawbacks.

Use of animal-derived components: While tissue engineering aims to reduce animal use, a major constituent of cell culture media still uses components of animal origin-mainly serum. Animal serum, like fetal bovine serum (FBS), is a supplement in culture media to provide hormones and various growth factors for cell development [39]. However, in addition to raising concerns for animal welfare and biosafety, animal serum's use decreases the reproducibility of experiments because of lot-to-lot variations [80-82]. Serum replacement will be discussed below.

High cost: 2D cell cultures show the potential to have relatively low costs, whereas advanced 3D culture systems are considered more expensive. However, price varies according to the 3D technique used. For some techniques, specialized equipment is required and contributes to raising expenses [83]. Therefore, different studies aim to develop and establish low-cost 3D cell culture techniques [84-86].

Time-consuming and low agreement for high throughput screening and automation: Some 3D cell culture techniques are technically demanding and time-consuming [84]. Therefore, they are not as suitable for high throughput screening as 2D systems [87-89]. Their automation also faces challenges. However, Aijian and collaborators have automated the hanging drop technique using digital microfluidics but at higher costs [90].

Variable reproducibility: The reproducibility of 3D appears to vary according to the technique used. For instance, scaffold-based systems seem to show poor reproducibility if animal-derived 
components are used [89], whereas scaffold-free methods are more successful [91,92]. For instance, the hanging drop method has shown nearly $100 \%$ reproducibility for numerous cell lines [91].

Lack of vasculature: The absence of vascularization in engineered tissue is a disadvantage for tissue transplants since it is a significant reason for poor graft take [93]. The development of endothelial capillaries within 3D engineered tissues could improve graft take [94,95] and contribute to creating a more relevant tumour microenvironment for cancer study models or studying angiogenic functions [78,96,97].

Lack of interaction with the immune system: A significant drawback of all in vitro models is that the created microenvironment does not include immunologic components, thus contributing to the gap between in vitro and in vivo models. The incorporation of immune cells and lymphatic capillaries to make cancer models more relevant is still a challenge but seems like a reachable objective $[78,96]$.

Difficulty to produce relevant scaffolds and to mimic complex structures: Finding prefabricated scaffolds that match the structure and mechanical properties of native organ ECM can be a challenge [98], as is the case, for instance, for blood vessels [99]. Therefore, using scaffold-free methods, like the self-assembly method, could prove advantageous $[89,98]$. Moreover, there are difficulties regarding the capability of producing complex 3D structures using cell culture. Three-dimensional bioprinting has allowed the production of complex structured scaffolds, but it still has many limitations [100].

Because of its various methods and relatively recent emergence, 3D cell culture is still challenging to standardize. Achieving a low-cost 3D culture that combines high throughput, reproducibility, time efficiency, and versatility remains a challenge but could lead to a decrease in animal use in agreement with the $3 \mathrm{R}$ principles.

Compared characteristics of animal and 2D and 3D cell culture models are presented in Table 1.

Table 1. Characteristics of animal models compared to 2D and 3D cell culture systems.

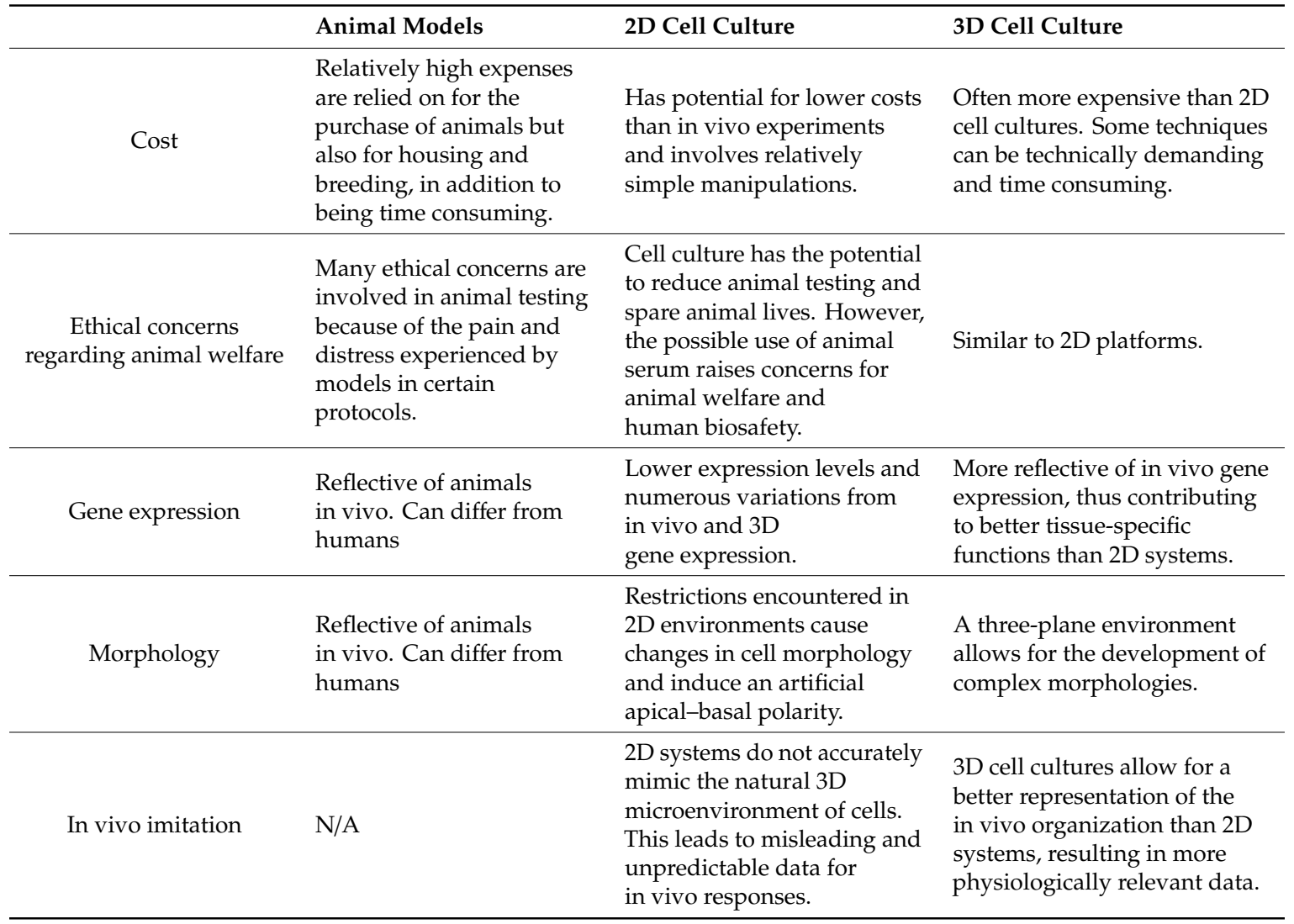


Table 1. Cont.

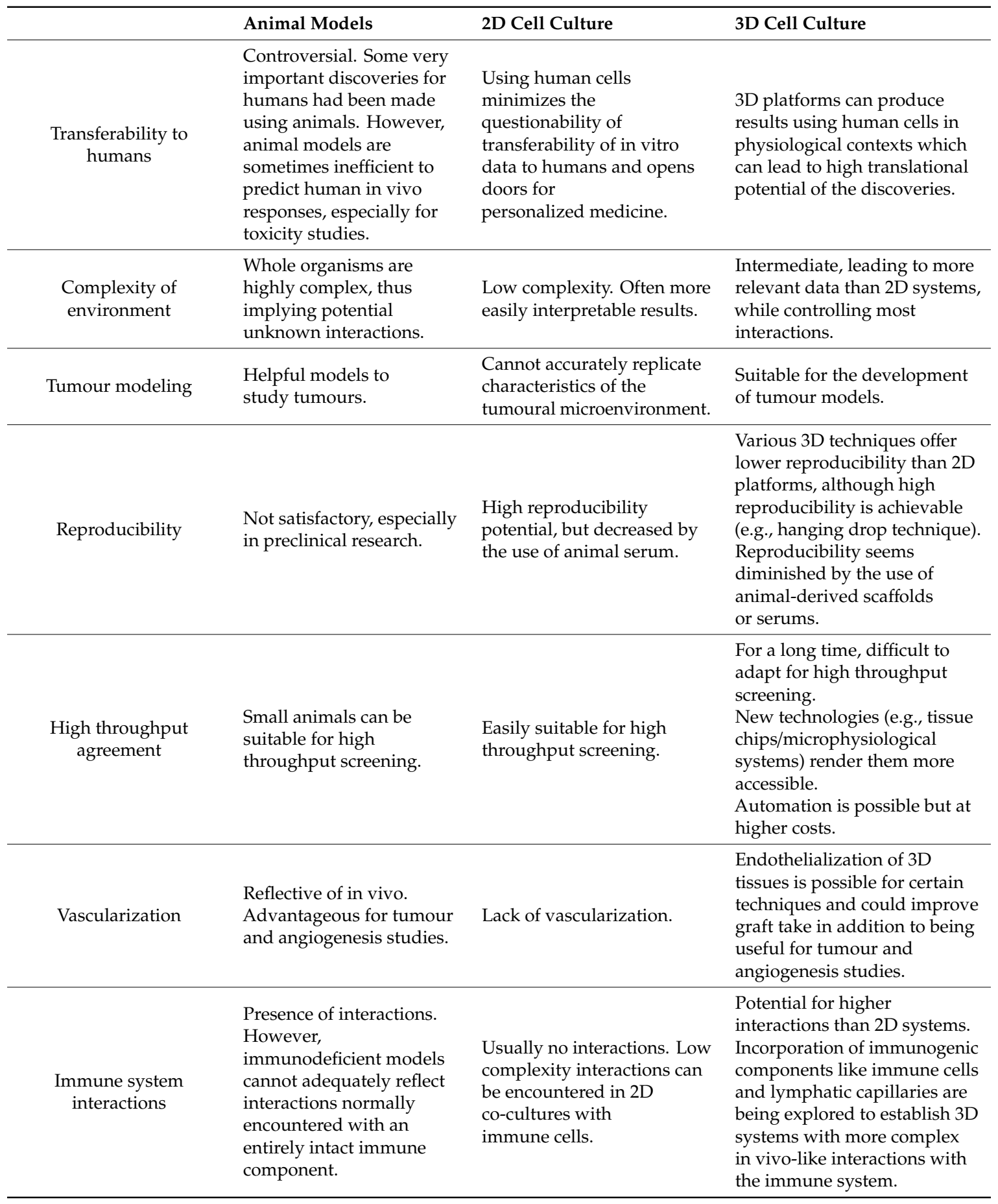

\section{Three-Dimensional Cell Culture Methods}

Advances in biological research have led to developments in cell culture to improve the current models used for in vitro studies. The emerging way to cultivate cells in a 3D manner rapidly gained popularity due to the possibility of overcoming the limitations of the 2D monolayer cell culture. Nowadays, many methods exist to produce a specific tissue in 3D cultures from cells that can then be used for research, transplantation, or drug development. The advantages and disadvantages of each method described in this review are summarized in Table 2. 
Table 2. Advantages and disadvantages of 3D cell culture protocols.

\begin{tabular}{|c|c|c|c|c|}
\hline $\mathrm{Me}$ & lods & Advantages & Disadvantages & References \\
\hline \multirow{3}{*}{$\begin{array}{l}\text { Synthetic } \\
\text { scaffolds }\end{array}$} & Metals & $\begin{array}{l}\text { Biocompatible } \\
\text { Great mechanical properties }\end{array}$ & $\begin{array}{l}\text { Potential poor biodegradability } \\
\text { Oxidation and aggregation issues } \\
\text { May require to be combined with } \\
\text { a polymer } \\
\text { Secondary release of metal ions may } \\
\text { cause toxicity }\end{array}$ & [101] \\
\hline & Ceramics & $\begin{array}{l}\text { Osteoconductive and } \\
\text { osteoinductive properties } \\
\text { (bioactive ceramics) } \\
\text { Composition can be similar to the } \\
\text { human bone mineral content }\end{array}$ & $\begin{array}{l}\text { Significant brittleness } \\
\text { May display inappropriate } \\
\text { degradation/resorption rates }\end{array}$ & [102] \\
\hline & Polymers & $\begin{array}{l}\text { Good tunability of physical } \\
\text { properties } \\
\text { Low immune response } \\
\text { Low production cost } \\
\text { High reproducibility } \\
\text { Defined purity and composition }\end{array}$ & $\begin{array}{l}\text { Often hydrophobic } \\
\text { Lack of cellular recognition patterns } \\
\text { for some of them } \\
\text { Poor biocompatibility } \\
\text { Risk of biodegradation side effects } \\
\text { (inflammation, toxicity, etc.) }\end{array}$ & {$[101,102]$} \\
\hline \multirow{4}{*}{$\begin{array}{l}\text { Natural } \\
\text { scaffolds }\end{array}$} & Polysaccharides & $\begin{array}{l}\text { High biocompatible } \\
\text { Low toxicity } \\
\text { Biodegradable } \\
\text { Often contain biofunctional } \\
\text { molecules, cell recognition patterns, } \\
\text { and adhesion sites on their surface } \\
\text { Similarity with native ECM }\end{array}$ & $\begin{array}{l}\text { Limited physical properties } \\
\text { Might contain pathological } \\
\text { impurities such as endotoxin } \\
\text { Difficult to process } \\
\text { Properties dependent on extraction } \\
\text { and processing procedures }\end{array}$ & {$[101,102]$} \\
\hline & Proteins & $\begin{array}{l}\text { Biocompatible } \\
\text { Biodegradable } \\
\text { Similarity with native ECM } \\
\text { Good interactions with the cells }\end{array}$ & $\begin{array}{l}\text { Limited physical properties } \\
\text { Low stability } \\
\text { Possible transfer of pathogens } \\
\text { Composition varies between } \\
\text { batches } \\
\text { Unidentified growth factors and } \\
\text { bioactive components }\end{array}$ & {$[102,103]$} \\
\hline & ECM-derived & $\begin{array}{l}\text { Natural ECM components } \\
\text { Good interactions with the cells } \\
\text { Contain biofunctional molecules } \\
\text { Minimal processing }\end{array}$ & $\begin{array}{l}\text { Uncertain composition } \\
\text { In-between lots variations } \\
\text { Risk of unwanted interactions or } \\
\text { interferences in signaling pathways }\end{array}$ & [104] \\
\hline & $\begin{array}{l}\text { Acellular } \\
\text { matrix }\end{array}$ & $\begin{array}{l}\text { Preservation of the native ECM } \\
\text { High biocompatibility }\end{array}$ & $\begin{array}{l}\text { Incomplete decellularization may } \\
\text { generate unwanted immune and } \\
\text { inflammatory responses }\end{array}$ & [105] \\
\hline Hydrogels & $\begin{array}{l}\text { Natural/ } \\
\text { Synthetic }\end{array}$ & $\begin{array}{l}\text { High water content } \\
\text { Can be made from a large variety of } \\
\text { natural or synthetic materials } \\
\text { Highly biocompatible } \\
\text { Controlled degradation rate } \\
\text { Highly tunable } \\
\text { Inexpensive } \\
\text { Co-culture possible } \\
\text { High reproducibility }\end{array}$ & $\begin{array}{l}\text { Limited physical properties } \\
\text { Gel-to-gel variations } \\
\text { Structural changes over time }\end{array}$ & {$[105,106]$} \\
\hline \multirow{3}{*}{ Scaffold-free } & Spheroids & $\begin{array}{l}\text { Simple protocols } \\
\text { Highly reproducible } \\
\text { Possibility to use multiple cell types } \\
\text { Size is easily tunable } \\
\text { Inexpensive }\end{array}$ & $\begin{array}{l}\text { Simplified architecture } \\
\text { Limited flexibility } \\
\text { Limited size } \\
\text { Lack of porosity } \\
\text { Lack of matrix interaction }\end{array}$ & {$[106,107]$} \\
\hline & Organoids & $\begin{array}{l}\text { Cells can be extracted from a patient } \\
\text { Great biomimicking abilities }\end{array}$ & $\begin{array}{l}\text { Has a certain variability } \\
\text { Hard to reach in vivo maturity } \\
\text { Lack vascularization } \\
\text { Can lack key cells types }\end{array}$ & [107] \\
\hline & Self-assembly & $\begin{array}{l}\text { Cells produce their own ECM } \\
\text { Cells can be extracted from a patient } \\
\text { Enable the formation of } \\
\text { tissue-mimicking organ-specific } \\
\text { tissue depending on the cell types } \\
\text { used }\end{array}$ & $\begin{array}{l}\text { Requires long culture time } \\
\text { Limited size } \\
\text { Limited mechanical properties } \\
\text { Lack vascularization } \\
\text { Incomplete cell differentiation alters } \\
\text { biomimicking properties. }\end{array}$ & [108] \\
\hline
\end{tabular}




\subsection{Scaffold Methods}

The most common way to cultivate cells in TE is to use a scaffold. A scaffold is a 3D structure made of synthetic, natural, or mixed components, on which cells can be seeded to form a tissue. Once the cells have populated the scaffold and started producing their own ECM, the scaffold is often degraded into by-products. The properties of the scaffold, such as permeability, surface chemistry, porosity, and mechanical characteristics, as well as its degradation profile and its ability to release biomolecules, contribute to mimic the cell's microenvironment $[107,109]$. The scaffold matrix closely interacts chemically and physically with the cells and directly influences their capacity to proliferate, differentiate, and secrete extracellular components [110]. Therefore, the choice of the matrix is heavily based on the cell type used and the nature of the study [111].

\subsubsection{Synthetic Scaffold}

Synthetic scaffolds are artificially made from organic or inorganic components such as metals, ceramics, and synthetic polymers. Compared to natural scaffolds, these materials, by their constitution, often lack biocompatibility with cells, sometimes requiring the encapsulation of signaling molecules, growth factors, hormones, or cellular markers to their surface, to ensure better cell proliferation and differentiation [110,112,113]. However, they usually have excellent physical properties, well-characterized components, and low risk of pathogen transmission, making them useful tools for tissue regeneration of cartilage and bones, for instance $[112,114,115]$.

Metals

Metal atoms have many exciting properties when combined into nanoparticles or porous materials. For instance, silver has toxic properties useful to limit unwanted contamination by microorganisms. Gold has good tunability, stability, and biocompatibility [116]. Finally, cobalt and nickel show magnetic properties when submitted to electromagnetic fields [117]. Palladium, titanium, and magnesium are also commonly used [118-120]. Many scaffolds using metal atoms have been developed over the past few years, improving their mimicking of the ECM and trying to overcome certain limitations such as oxidation and aggregation issues [118,121].

Porous metallic materials have a wide-spaced rigid structure with low density and high mechanical strength, closely resembling the bone in vivo. Their shape and permeability are ideal for cell infiltration of the scaffold with good diffusion of nutrients, oxygen, and metabolic waste $[120,122]$. Their porosity is highly tunable, affecting the stiffness and strength of the scaffold, the diffusion capacity, and the extent of the migration of the cells, playing with the density of the tissue generated $[123,124]$. Biodegradable porous metallic scaffolds can be made by selective laser melting [125], powder metallurgy [126], injection of inert gas into a melt [127], sintering of particles [128], vacuum foaming [129], investment casting [130], thixocasting [131], and other methods [122].

Metal nanoparticles can be combined with a polymer to form a polymer or hydrogel nanocomposite [132,133]. This type of scaffold prevents the nanoparticles from aggregating while preserving their properties. The polymer used can be of natural (polysaccharides, proteins) or synthetic (polymeric acids, polyvinyl alcohol) nature. The nanoparticles notably improve the mechanical properties, the thermal stability, and the electrical conductivity of the polymer matrix [134]. They also provide the scaffold with a broad-spectrum antibacterial activity [135]. Polymer nanocomposites are mainly made by melt mixing, by in situ polymerization of a monomer in the presence of metal nanoparticles, or by the in situ reduction of metal salts/complexes in a polymer matrix [136].

Novel approaches combine metals with natural ECM components to generate hybrid scaffolds with excellent biological properties while preserving good structural strength. For example, a team in California developed a new scaffold using a stainless-steel mesh coated with bovine and rat collagen that could be beneficial in cardiac and vascular membrane grafts [137]. 


\section{Ceramics}

Bioceramic-based scaffolds are mainly used in bone and dental TE $[138,139]$. The term bioceramic refers to a class of ceramic materials that have biocompatibility with the human body. They are made from stable components that can be either biologically active or inert [138]. These materials also have excellent physical stability, antibacterial effects, and antithrombus effects [140]. They have chemical structures that closely resemble the inorganic components of human bones [141]. They offer a 3D porous structure that enables an effective diffusion of nutrients and metabolic wastes, thereby allowing cell migration and ingrowth of the tissue from the periphery toward the inner center of the scaffold [142]. In particular, the porosity and the interconnection of the pores expand the surface area while creating roughness on the scaffold's surfaces, promoting osteoblasts adhesion with the scaffold [143]. However, generating a ceramic scaffold with porosity and pore sizes as high as a human bone significantly decreases its structural strength $[144,145]$.

Common ceramic materials used in TE are calcium phosphate, hydroxyapatite, tricalcium phosphate, biphasic calcium phosphate, calcium silicate, tricalcium silicate, and bioactive glasses. Particular ions, such as zinc, strontium, magnesium, and manganese, can also be incorporated into the scaffold, adding interesting properties to it and promoting better cell differentiation into osteoblasts [146]. Bioactive glasses are mainly composed of $\mathrm{Na}_{2} \mathrm{O}, \mathrm{CaO}, \mathrm{SiO}_{2}$, or $\mathrm{P}_{2} \mathrm{O}_{5}$ [147]. They possess an interesting osteoconductivity and osteoproductivity, favouring progenitor cells' proliferation and differentiation [148]. In controversy, they have a significant brittleness that can cause the collapsing of the highly porous structure, thereby altering the tissue ingrowth [138].

Ceramic scaffolds can be made by gas foaming [149], freeze-drying [150], fibre bonding, particulate/salt leaching [151], emulsification [152], phase separation/inversion, and, more recently, 3D printing [138]. In general, scaffolds are designed to mimic as closely as possible the in vivo environment. Three-dimensional printing of ceramic scaffolds offers a tunability of many parameters (porosity, pore shape, pore interconnectivity, architecture) that cannot be achieved by more traditional fabrication methods [146].

\section{Polymers}

Polymers are an assembly of a repeating subunit and form interesting materials for TE. Synthetic polymeric scaffolds are commonly made of polyesters, polyether esters, polyurethanes, and synthetic silks [153]. Polymers can be massively produced with controlled composition and molecular weight with no variability between the different production lots [154]. They can be made by solvent casting [155], particulate leaching [156], electrospinning [157], emulsion freeze-drying [158], phase separation [159], melt molding [160], selective laser sintering [161], stereolithography [162], fused deposition modeling [163], and 3D printing $[164,165]$. The high tunability and reproducibility of polymers are ideal for scaffolds with specific properties [153]. A synthetic polymer can also be combined with a synthetic or natural polymer to generate a scaffold with complimentary properties from both materials [166].

A significant drawback of the use of synthetic polymeric scaffolds is that their matrix lacks cell recognition signals for proper cell adhesion to the scaffold, particularly compared to natural scaffolds [167]. Therefore, cell adhesion molecules, proteins, and growth factors must be added to the matrix to better mimic the cell microenvironment and to have a desirable tissue ingrowth [168]. Furthermore, some polymers such as poly ( $\alpha$-hydroxy esters) generate acidic by-products when they are degraded by the cells, changing the $\mathrm{pH}$ of the medium that diminishes cell proliferation and alters their survival. This $\mathrm{pH}$ change can also lead to an inflammatory response to the graft [169]. With that in consideration, synthetic polymeric scaffolds still have lower immunogenicity and a reduced risk of graft rejection because of their lack of bioactivity compared to natural scaffolds [170].

\subsubsection{Natural Scaffolds}

Over the years, natural scaffolds have been preferred over synthetic scaffolds in TE because of their inherent biocompatibility [113]. In general, scaffolds are designed to closely mimic the cell 
microenvironment to enable proper cell proliferation and differentiation [154]. Natural scaffolds easily achieve this objective without requiring the encapsulation of cell signaling molecules and growth factors into the matrix [171]. Moreover, they have an excellent degradation profile where only non-toxic by-products are generated [113]. Natural scaffolds include polysaccharides, proteins, ECM-derived scaffolds, and acellular matrices. They are produced by living organisms such as bacteria, yeast, plants, and animals [172-174].

Consequently, unknown exact composition and in-between lots variations are some limitations of this cell culture method [103]. Natural materials are not always easily processed into the required shapes and sizes [113]. They also have a higher risk of pathogen transmission and graft immunogenicity than synthetic scaffolds $[114,170]$.

\section{Polysaccharides}

Natural polymers are interesting candidates to form 3D scaffolds. Polysaccharides are a type of natural polymers commonly used in TE.

Chitin is a substance found in the composition of the exoskeleton of crustaceans and insects, or fungi. While this material lacks essential properties for TE, it can undergo deacetylation via chemical hydrolysis in alkaline conditions or by enzymatic hydrolysis, to generate a copolymer of randomly distributed $N$-acetyl D-glucosamine and D-glucosamine subunits $[175,176]$. Because of its interesting properties, this newly formed material called chitosan is widely used in various fields such as wound healing, bone tissue regeneration, and drug delivery [177]. Chitosan is slightly positive at acidic conditions due to its amino groups, which enable interactions with negatively charged molecules and membranes. It has good biocompatibility, degradation profile, and mucoadhesivity, and is non-toxic and non-antigenic. It also has antibacterial properties as well as high adsorption properties [176,178]. However, this material has weak physical strength. This limitation can be overcome by combining chitosan to materials with better mechanical properties like calcium phosphate, hydroxyapatite, or silk [179]. In industry, chitosan is mainly produced by fungi since it offers a more controlled and scalable production with less lots of variation [177].

Alginate is a primary component of cell walls of brown seaweed and bacteria $[180,181]$. This polysaccharide's subunits are $\beta$-D-mannuronic acid and $\alpha$-L-guluronic acid through a $(1 \rightarrow 4)$ linkage, which confers a $\mathrm{pH}$-dependent negative charge to the material. Playing with the subunits ratio gives tunability to alginate for mechanical and biological properties $[179,182]$. This low-cost material is hydrophilic, biocompatible, has a good degradation profile into non-toxic by-products, is non-antigenic, and can be chelated with cations into microspheres [183,184]. Alginate can be turned into hydrogels and porous scaffolds by various crosslinking methods such as phase transition and free radical polymerization or freeze-drying and electrospinning [181]. It is easy to manipulate and to form scaffolds of different shapes and sizes with it. On the downside, alginate, by its composition, lacks cell recognition patterns, sometimes resulting in lower cell adhesion. Therefore, cell receptors and signaling molecules into the matrix might be required [185]. Recently, new advances have been made to produce a new form of cellular building blocks that can be self-assembled into complex tissue constructs. Tissue strands (Figure 4) are made by injecting a cell suspension through a semi-permeable tubular alginate capsule. These capsules are made with a coaxial nozzle apparatus and have low variability in shapes and sizes. Once the cells are injected into them, these capsules have their end tied using vessel clips. Following a five-day culture, the alginate is then dissolved with a $1 \%$ citrate solution, leaving pure cellular strands. These tissue strands can then be cut into smaller pieces to be assembled or be used as bioink to form larger tissues [186,187]. During the deposition of the cell pellet, alginate porogens can be added to the cellular suspension to form porous tissue strands. This allows for a better diffusion of nutrients and metabolic wastes and enhances cell survival [188]. 

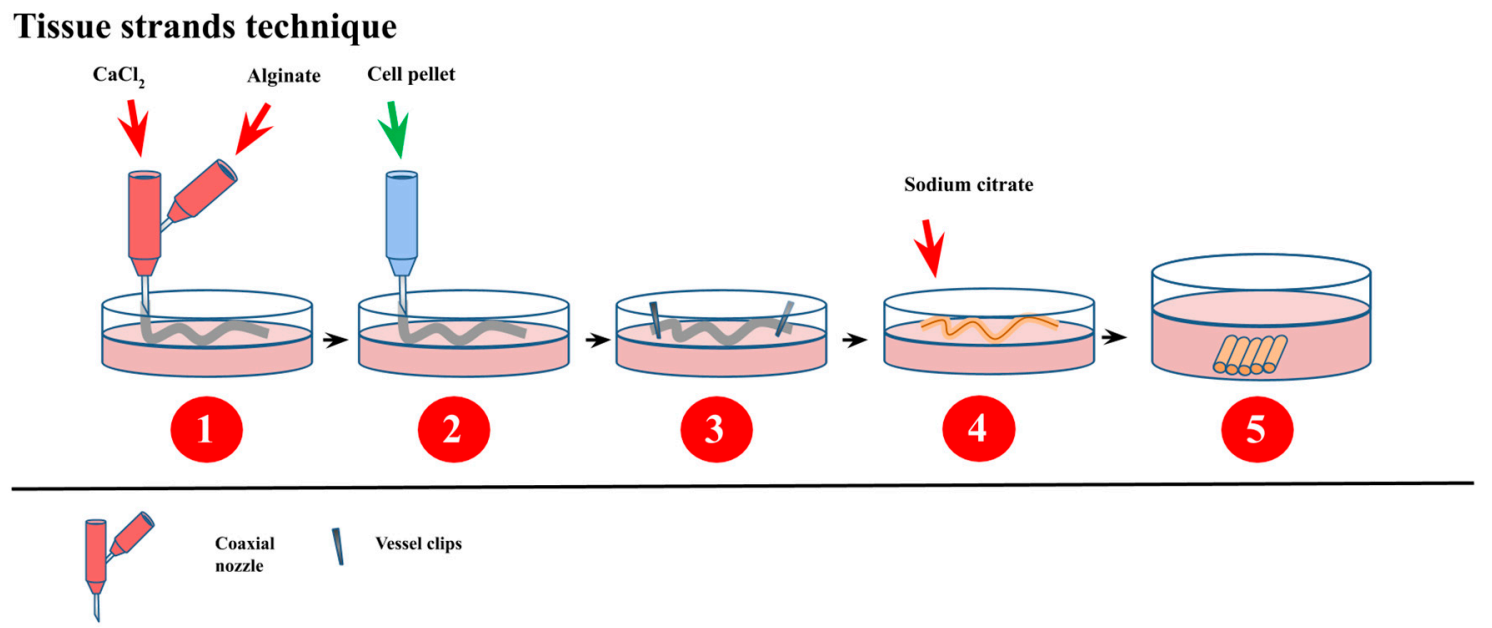

Figure 4. Schematic description of the tissue strands technique based on the ability of the cells to self-assemble into a tissue. Sodium alginate and a crosslinker solution are used to form tubular alginate capsules with a coaxial nozzle into a cell culture dish. Once polymerized, the capsules are filled with a cell pellet, and their ends are tightly sealed with vessel clips. After a 5-7 day culture, a sodium citrate solution is added to depolymerize the capsules, leaving complete and dense tissue strands that can later be used as building blocks to form complex larger tissues [186].

Hyaluronic acid is a natural linear polysaccharide found amongst others in conjunctive, epithelial, and nervous tissues of vertebrates. It is composed of repeating $\mathrm{N}$-acetylglucosamine and D-glucuronic acid units and has an anionic charge at physiological $\mathrm{pH}[189,190]$. This material is biocompatible since it is a primary component of the ECM, has a characteristic viscosity and elasticity, and good biodegradability. Mainly formed into hydrogels, it is known to induce osteogenic differentiation and regulate bone tissue formation [191]. Hyaluronic acid and its derivatives can be chemically modified with ease to gain desired functions and have low immunogenicity [190,192].

However, they have poor mechanical properties and can be hard to manipulate into desired scaffolds [102]. Even though hyaluronic acid originates from animals, it is nowadays produced by microbial fermentation [193].

Cellulose is commonly found in bacteria, tunicates, and plants, a primary component of their cell walls. It is formed of repeating $\beta$-D-glucose with a $\beta(1 \rightarrow 4)$ link [194]. Depending on its origin, cellulose might have slightly different properties when shaped into scaffolds [195]. In general, this material has excellent biocompatibility and mechanical strength, is hydrophilic, has practical optical transparency, and is inexpensive. Other polymers can be mixed with cellulose to add specific properties to the scaffold [196]. It also enables proper cell adhesion, proliferation, and osteogenic differentiation. Thus, it is a good candidate for bone tissue reconstruction and medical implants [179]. A particular limitation to cellulose is that it has a low degradation rate in vivo, which can be problematic for tissue transplants [102].

\section{Proteins}

Natural polymers can also be made of proteins and peptide strands that can be shaped into scaffolds for 3D cell cultures.

As one of the ECM's primary components, collagen is the most abundant protein in humans and is responsible for maintaining structural integrity in various tissues $[197,198]$. It, therefore, has inherent biocompatibility and low antigenicity [199]. Collagens are a group of triple $\alpha$-helix proteins. Type I, II, III, and V are the ones most found in the ECM with the ratio depending on the tissue type [200]. Collagen fibres are highly tunable and can easily be shaped into porous scaffolds or hydrogels [179]. They provide excellent support for cell proliferation and are degraded by cell enzymes. Cells can attach to the matrix through their integrins, thereby activating cell survival pathways [201]. On the downside, collagen scaffolds generally have low mechanical strength $[202,203]$. The primary production method 
is the extraction of collagen-rich tissues such as skin, tendons, intestine, and bladder from animals or human sources. The collagen fibres are then collected through a purification process of the tissue [204]. Even though collagen is an excellent candidate for 3D scaffolding, the necessity to use animals for its production is not in harmony with the $3 \mathrm{R}$ principles. Nevertheless, new options have emerged, such as recombinant human collagen produced in tobacco plants at a low cost [205].

Gelatin is a polymer directly derived from type I collagen that has undergone irreversible hydrolyzation through heat and enzymatic processes. It is a mix of proteins, mineral salts, and water [206]. This material has gained interest in TE because of its biocompatibility, biodegradability, and antigenicity. It promotes cell adhesion and is usually non-toxic, although this property may vary depending on the crosslinking reagent used [207-209]. Due to its weak mechanical properties when turned into a scaffold, it is commonly mixed with synthetic polymers to improve this parameter [210]. Gelatin is extracted from various animal sources such as cows, sheep, pigs, fish, and even insects [206]. Like collagen, this material conflicts with the $3 \mathrm{R}$ principles.

Fibrin is a natural protein playing an essential role in wound healing in the human body. Following an injury, fibrin aggregates serve as a structure for cells to adhere to and secrete new ECM components [211,212]. Fibrin is produced upon the interaction of fibrinogen with thrombin, as part of the coagulation cascade [213]. Therefore, fibrin scaffolds have inherent biocompatibility with high cell affinity and rapid degradability [214]. The scaffold made from fibrin fibres closely mimics the ECM and promotes cell proliferation, especially when mixed with growth factors and endogenous molecules [215]. The properties of this material are highly tunable by varying the initial concentrations of fibrinogen and thrombin. However, fibrin might require to be mixed with another polymer to overcome the weak mechanical properties and the rapid degradation rate of this material [216]. In an autologous context, fibrin can be generated from fibrinogen and thrombin extracted from the blood of the patient [217].

Silk is naturally made by certain Lepidoptera larvae, some arachnids, and a few flies [218]. It is composed of two fibroin fibres linked together by a triangle cross-section made of sericin proteins [219]. Its composition may vary depending on its origin. To be used as a scaffolding material, the sericin part of the silk needs to be removed [220]. Silk fibroins are highly biocompatible, have excellent mechanical properties, and have a good degradation profile where their by-products can be absorbed [219]. This material can be easily manipulated, and endogenous molecules can be encapsulated. Production of silk fibres is mainly made by extraction from lepidopteron insects of Bombycidae or Saturniidae families [218], but recombinant proteins are emerging [221].

As part of our alimentation and gaining interest because of its benefits on our health, it was recently reported that soy proteins, extracted from soybeans, were considered a potential candidate to replace animal-derived ECM proteins as scaffolding materials [222]. They have excellent biocompatibility and generate non-toxic by-products when degraded. This low-cost material can be turned into porous scaffolds or hydrogels and induce cell proliferation and survival $[223,224]$. Soy proteins, due to their low molecular weight, are highly prone to rapid enzymatic degradation. To overcome this limitation, mixing with synthetic polymers or crosslinking reagents is a way to improve soy scaffold's mechanical properties. However, some crosslinking reagents are toxic to the cells, while synthetic polymers might have unwanted properties [222,225]. The use of soy protein scaffolds for TE still requires some improvements, but it has great potential, since it is a good example of an alternative solution to reduce animal use in research.

\section{ECM-Derived Scaffold}

Some scaffolding materials can be directly extracted from the cellular microenvironment. This is the case for Matrigel ${ }^{\circledR}$, a material made of ECM components of Englebreth-Holm-Swarm mouse tumours [226]. It contains structural proteins such as collagen, laminin, and enactin, as well as various growth factors [227]. Since Matrigel ${ }^{\circledR}$ is naturally produced and extracted through a relatively minimalistic procedure, its physical and chemical properties can be maintained to accurately mimic 
the ECM [228,229]. Mainly used as a hydrogel, it supports cell survival and proliferation [104]. This mixture of ECM components has been proven useful in various domains, such as cancer and stem cell research [227]. By an unknown mechanism, Matrigel ${ }^{\circledR}$ helps maintain the pluripotency of stem cells in culture [227]. Since it is extracted from tumours in an animal, in-between lots variations and uncertain composition and concentration of components are a significant issue with this material [103]. Once considered as the gold standard scaffolding material in TE, this product is furthermore based on the inoculation and development of cancer tumours in mice for ulterior sacrifice and collection of extracellular matrices. This procedure is derogatory to the $3 \mathrm{R}$ principles, and alternative culture methods should be favoured.

Acellular Matrices

Tissues taken from living sources can undergo a decellularization process to remove all cells from its ECM. The resulting matrix is made of structural proteins such as collagen and glycosaminoglycans, and endogenous molecules [230]. In various domains such as cardiac surgery and breast reconstruction, it is used as scaffolding material. It provides an authentic physiological microenvironment for cells to grow into a specific tissue from which the scaffold is derived [231,232]. Commercially available acellular matrices can also be a synthetic mixture of many ECM components from different tissue sources [230].

Since acellular matrices can be extracted from a large variety of tissues with different properties, many decellularization protocols have been developed throughout the years [233]. Decellularization is possible by a chemical, biological, or physical approach, or a combination of the three. Chemical decellularization includes the use of detergents and alcohols, acid-base reactions, and hypotonic-hypertonic reactions. The biological approach is based on the use of enzymes such as collagenase, trypsin, or nuclease to remove all cells. Decellularization by physical methods includes mechanical abrasion, electroporation, and temperature and pressure treatment [230]. The objective is to remove all cellular components while preserving, as much as possible, the ECM components and structure for their excellent biomimicry properties.

Acellular matrices as bioscaffolding materials have significant interactions with the cells for proper survival, proliferation, and differentiation. Since collagen, amongst other ECM components, is highly preserved across species, they have high biocompatibility and generally do not generate a significant immune reaction in the host $[234,235]$. However, the complete decellularization of the tissue requires an intensive protocol that sometimes denatures ECM components and alters its structural properties. This results in variation between the scaffold and the in vivo ECM that can affect cell behaviour and limit cellular colonization [231]. Furthermore, the sterilization of the acellular matrix scaffold can be difficult or incomplete. Simple sterilization treatments like incubation with solvents do not provide sufficient penetration to the core of the scaffold. More drastic methods, like gamma irradiation and ethylene oxide exposure, affect the structural and mechanical properties of the scaffold [233].

With current techniques and scaffolding materials, acellular matrices are the ones that undoubtedly better mimic the microenvironment of the cells. However, these materials originate from tissues taken from living organisms. While this method is interesting in an autologous context, the use of animal tissues for cell culture purposes does not respect the 3R principles.

Regarding the $3 \mathrm{R}$ principles, not all scaffolding materials that contribute to reducing animal use in TE. Even though synthetic materials are made artificially without involving living organisms, they have limited biological properties compared to natural materials. While microorganisms make some natural materials, some of them still require tissues from animal sources to be formed. Therefore, methods respecting the $3 \mathrm{R}$ principles should be privileged, and improvements should be made to overcome their limitations.

\subsubsection{Hydrogels}

Hydrogels are made from natural or synthetic hydrophilic polymers or a mix of both types such as poly(ethylene oxide), poly(vinyl alcohol), polypeptides, agarose, or gelatin. The difference with 
previously described scaffolds resides in their water content. In the case of hydrogels, water is up to $95 \%$ of the volume [236,237]. This propriety has the distinct advantage to enable easy access to nutrients, growth factors, and oxygen to cells proliferating through the scaffold [238]. It also improves the biocompatibility of the scaffold [239]. Hydrogels are highly flexible while having adequate structural stability $[104,106]$. Their water retention and their soft rubberish surfaces resemble human tissues [239].

These scaffolds have an excellent tunability for 3D cell culture [107]. For instance, their degradation rate can be easily modified by changing the number of crosslinks between polymers [240]. However, they have some limitations. Since endogenous factors are not embedded directly into the matrix, an uneven gradient of soluble factors can alter proper cell differentiation. The particular architecture of the scaffold also makes it harder to do cell imaging and analysis than other types of scaffolds: Cells can have limited accessibility for immunostaining. In addition, light scattering, refraction, and attenuation occur in 3D composite cell-laden gel [241].

Hydrogels can be made from physical or chemical crosslinking of polymers [242]. Nowadays, common fabrication methods are 3D printing [243], layer-by-layer fabrication [244], microfluidic-based fabrication [245], and self-assembly [242].

\subsection{Scaffold-Free Methods}

The first method developed to cultivate cells without any external structural support was the hanging drop technique and was introduced by Johannes Holtfreter in 1944. Initially used for the culture of embryonic stem cells, it is nowadays primarily used to generate spheroids [246]. This method opened a new path of techniques that do not rely on the scaffold to form a tissue of interest. Since the introduction of the hanging drop technique, the term "scaffold-free" has been given various definitions and covers a large number of techniques (Figure 5).

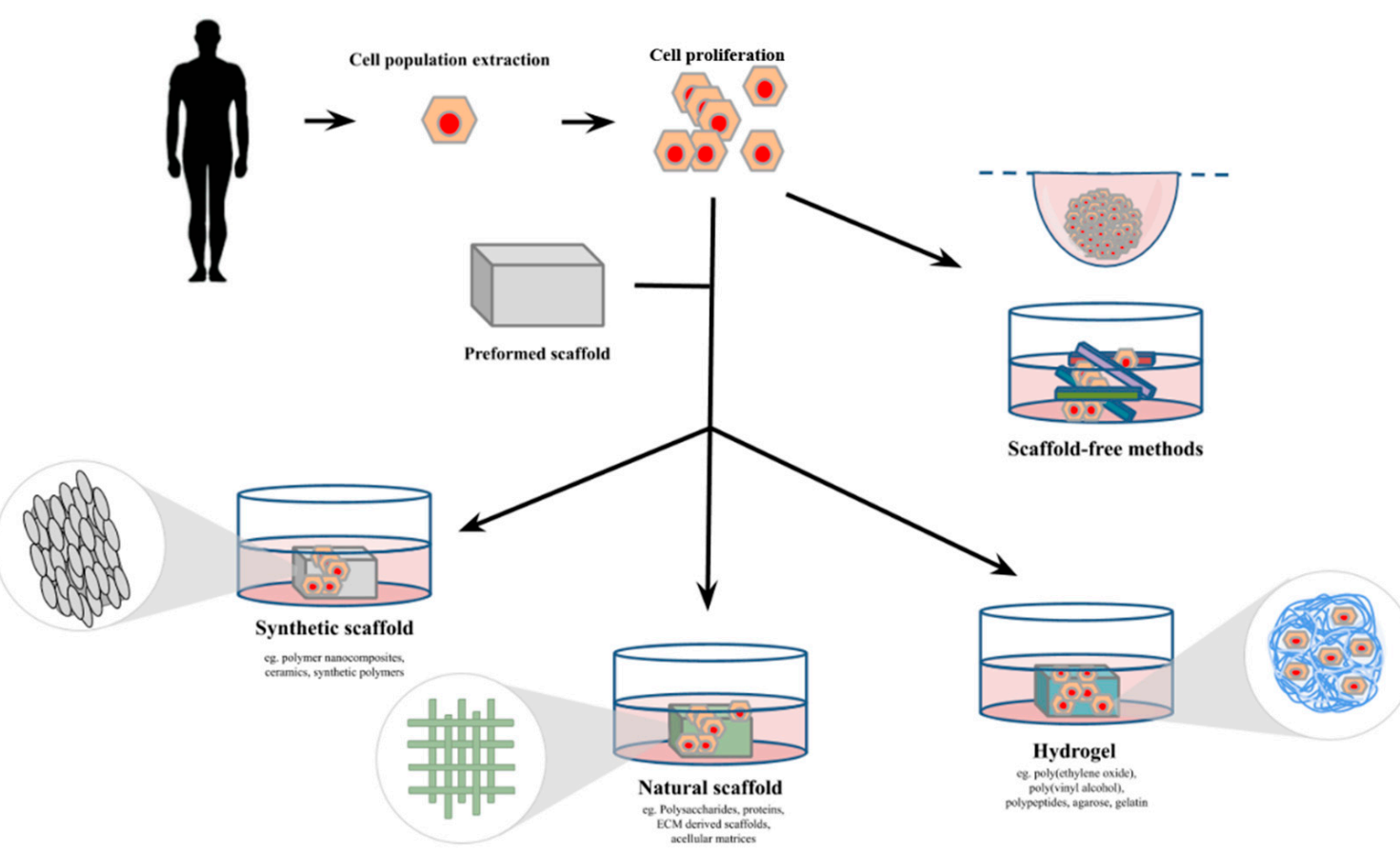

Figure 5. Scaffold vs. scaffold-free 3D cell culture.

\subsubsection{Principles}

In vivo, stromal cells, mainly fibroblasts, are surrounded by structural proteins such as collagen and laminin, and endogenous molecules secreted by the cells. This microenvironment composition varies depending on the tissue source and localization in the organism. Interacting with the cells through signaling pathways affects their growth, differentiation, migration, and apoptosis, thereby 
regulating the tissue properties and specificity $[247,248]$. When cultured in vitro under optimal conditions, cells can produce and deposit their matrix components to form an ECM similar to the one found in vivo. The scaffold-free methods rely on this ability to generate a specific tissue from the self-aggregation of cells producing their 3D matrix [96,110,249].

\subsubsection{Spheroid}

Spheroids are spherical 3D cell aggregates in suspension [249]. They were first developed by Sutherland and coworkers in 1970 to recapitulate human tumours' functional phenotype [250,251]. Due to their 3D structure, outer layer cells are directly in contact with the culture medium, while cells in the inner core only obtain nutrients and oxygen by diffusion. This results in a proliferative cell activity on the perimeter of the spheroid and a hypoxic central zone with quiescent and necrotic state cells, particularly in large spheroids where diffusion is inefficient. This cellular heterogeneity contributes to mimic cancer tumours in vivo $[53,103]$ closely. Spheroids can be made from one or many cell types and can be of various sizes, depending on the initial cell deposit [110]. They have many great utilities ranging from cancer invasion profiling to drug screening $[77,252]$. Spheroids are mainly made of four methods.

\section{Hanging Drop Technique}

The hanging drop technique, like suggested by its name, is done by inverting an upside-down Petri dish top cover containing droplets of cell suspension. The bottom of the Petri dish contains sterilized water to maintain a specific humidity level [253]. By microgravity, all the cells go at the bottom of the drop to the air/liquid interface [254]. Without adhesion to a surface, cells aggregate themselves to form a dense sphere [91,249]. A maximum of $50 \mu \mathrm{L}$ of cell suspension can be deposited onto the cover. Otherwise, the surface tension is too weak to maintain the drop in place [255]. The spheroid size is controlled by the initial number of cells suspended. The co-suspension or consecutive addition of multiple cell types allows the formation of multicellular spheroids with distinct cell layers [110]. The hanging drop method is simple to use and highly reproducible with the formation of one spheroid per drop with low parameter variability [91]. Since this method is not suitable for frequent media change, large spheroids might require a transfer to a propagation plate with higher media volume to ensure proper culture conditions [110].

\section{Low-Attachment Plates}

An alternative method to produce spheroids is by using low-attachment plates. Often made of polystyrene treated with hydrophilic or hydrophobic coatings preventing cellular attachment, their wells are suited for producing a single spheroid [256]. By containing many wells and having a large volume, low-attachment plates are frequently used for multicellular spheroids culture in cancer research [110]. The cell suspension is seeded into individual wells and is incubated. Cell media can be changed frequently with automated instruments [257].

\section{Magnetic Levitation}

The magnetic levitation method is an upgrade from the low-attachment plate method to produce spheroids. It relies on the use of magnetic nanoparticles. Before being seeded into the wells of a low-attachment plate, the cells are mixed with magnetic particles. During the culture, a magnetic field is applied to elevate the cells toward the air/liquid interface, promoting contact between cells and their differentiation to form a dense aggregate [110]. This method is well suited for co-culturing multiple cell types for the production of heterogenic spheroids $[258,259]$. 


\section{Bioreactor}

Another method for producing spheroids is by using a bioreactor. Bioreactors can be classified into four categories: spinner flask bioreactors, rotational culture systems, perfusion bioreactors, and mechanical force systems $[260,261]$. The general principle for the formation of spheroids is the same for all the types of bioreactors: a cell suspension with optimal density is filled into a chamber that is constantly shaken, either by stirring, rotating, or perfusing the culture media through a pumping system. This movement allows the cells to aggregate. Bioreactors also have flowing systems to generate movement of nutrients and metabolic wastes and maintain homogeneity of the physical and chemical factors within the chamber. This method is made for large scale production, although a significant variability is observed between the spheroids. Moreover, it does not allow any control over the spheroid size and cell number [106,262].

\subsubsection{Organoids}

The term "organoid" means self-renewing 3D cultures derived from primary tissue, embryonic stem cells, or induced pluripotent stem cells (iPSCs) that have a similar organization and functionality as the tissue/organ from which the cells originate or to which they are differentiated to, in the case of iPSCs [110]. Organoids can be classified depending on if they are formed from tissue or stem cells. Tissue organoids are mostly comprised of epithelial cells with no stroma. Stem cells organoids are made of embryonic stem cells or induced pluripotent stem cells or primary stem cells extracted from neonatal tissue or specific organs [107]. This type of culture is based on stem cells' ability to self-organize in vitro into a tissue sharing the structural and functional properties of the organ or tissue from which the cells originate [263]. Organoids have been used to mimic organs such as the brain [264], retina [265], stomach [266], lungs [267], thyroid [268], small intestine [269], liver [270], kidneys [271], and many more. They can be used in various domains, such as human pathologies and cancer research [263]. Many methods are used to produce organoids. Cells can be directly cultured into a 2D monolayer on a bed of feeder cells or an ECM-coated scaffold to form the organoids after cell differentiation. Cell cultures can also be supported mechanically to allow further differentiation of primary tissues. The hanging drop or the low-attachment plate techniques can be used to generate embryoid bodies. Finally, the serum-free floating culture of embryoid body-like aggregates can be made with quick reaggregation in low-attachment plates [107].

\subsubsection{Microfluidic}

Microfluidic systems are an improvement of the scaffold-free methods for a better mimicry of a living organism. They provide a continuous supply of nutrients and oxygen while removing metabolic wastes, creating an artificial network. This enables the production of large engineered tissues and the assembly of multiples organoids or spheroids to generate in vitro a whole system [103,272]. Microfluidic systems also allow precise culture conditions and better monitoring of the cells [273].

\subsubsection{Self-Assembly Method}

In 1972, B.R. Switzer and G.K. Summer showed that ascorbate, an enzymatic cofactor of lysyl- and prolyl-hydroxylase, stimulates the production of collagen type I by human dermal fibroblasts when added into the culture media [274]. Indeed, ascorbic acid facilitates the proline's hydroxylation, which is crucial for collagen fibrils stability and their deposition [96]. This was followed by a groundbreaking experiment done by R. Hata and H. Senoo in 1989. They demonstrated that dermal fibroblasts could deposit and organize enough ECM components within a few days of culture to create a 3D stromal sheet that can be stacked or rolled to form a 3D organ substitute [275]. This led to a whole new way of producing engineered tissues without requiring external support (Figure 6). 


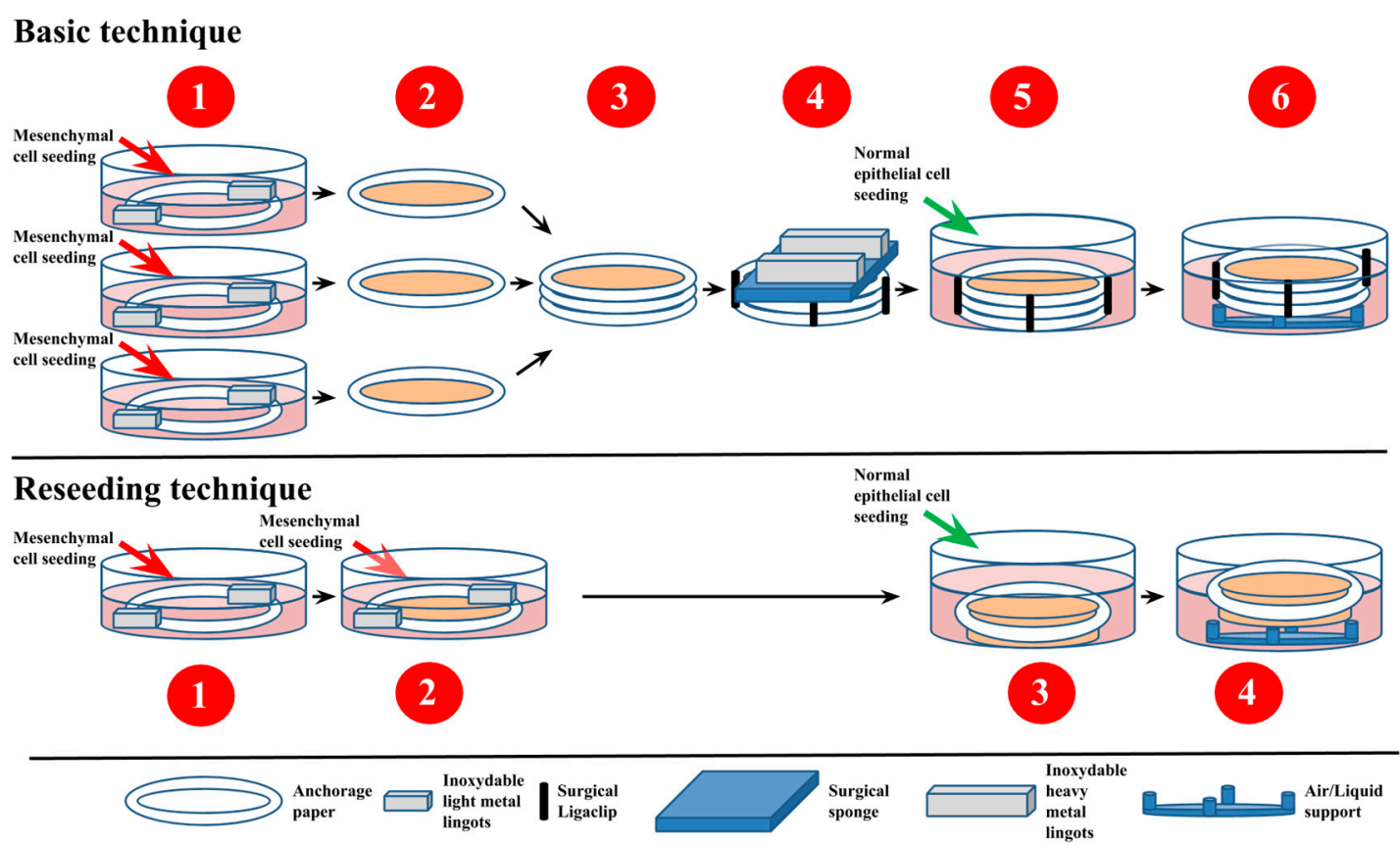

Figure 6. Schematic description of the basic and the reseeding self-assembly techniques used in Tissue Engineering. For the basic self-assembly technique, mesenchymal cells are seeded into three cell culture dishes containing a paper anchor and rust-resistant light metal weights at the bottom. After 28 days in culture with ascorbate, the stromal sheets formed are stacked upon each other for a variable time with a mechanical load composed of a surgical sponge and rust-resistant heavy metal ingots and with surgical Ligaclips to ensure the fusion of the sheets. Epithelial cells are seeded on top of the construct, and the culture is continued for seven more days. After that, tissues are mounted onto supports and maintained at the air/liquid interface for 21 consecutive days to ensure a complete maturation of the epithelium. The first step for the reseeding self-assembly technique is similar to the one for the classic self-assembly technique. However, instead of stacking the stroma sheets later, mesenchymal cells are reseeded on top of the stroma sheets after 14 days of culture with ascorbate. Fourteen days later, epithelial cells are seeded on top of the stroma sheets, and the culture is continued for an additional seven days. The tissue constructs are then maintained at the air/liquid interface with support for 21 days to ensure a complete maturation of the epithelium [108].

Protocol

To generate a complex human tissue construct, cells firstly need to be extracted and isolated from a patient/volunteer's biopsy. The biopsy is cleaned with a sterile saline solution containing antibiotics. The stroma and the epithelium are enzymatically separated using thermolysin. Then, collagenase can be added to the stroma to extract mesenchymal cells. Trypsin can be used to extract epithelial cells from the epithelium. By adding $50 \mu \mathrm{g} / \mathrm{mL}$ of ascorbic acid into the media throughout the mesenchymal cells culture time, these cells produce and assemble their own ECM components [276]. This enables the formation of stromal sheets that can be collected by forceps and stacked to be used as cellularized scaffolds. Instead of being stacked, stroma cells can also be reseeded onto a stromal sheet, resulting in a more thick and solid cellular sheet. Then, epithelial cells can be seeded onto this assembled stroma. After a week in culture to allow a full cover of the apical region by the epithelial cells, the cellular sheets are maintained for 21 days at an air/liquid interface to induce the maturation of the epithelium cells. Thereby, engineered cellular assembly mimicking the native tissues is obtained and can be used as models for research or as grafts for autologous transplants $[96,108]$. 
Current Tissues Produced Using the Self-Assembly Technique

Several tissues have been obtained using the self-assembly method developed at LOEX by Dr. François A. Auger and coworkers (Figure 7 and Table 3). These tissues can be used for pathological and pharmaceutical research, and can be transplanted in patients. Skin, blood vessels, corneas, urological tissues, adipose tissue, bone, and vaginal mucosa can be made using the self-assembly method. Skin tissue is obtained by stacking the dermal fibroblast-derived stromal sheet after four weeks of culture seeded with keratinocytes that form the epidermis [276]. The self-assembly model of skin is currently used to help wound healing of severely burned victims $[277,278]$. Corneal tissues can be obtained using epithelial, stromal (keratocytes), and corneal endothelial cells [279]. Bladder and urethra tissues could be made from skin fibroblast or bladder mesenchymal cells, for the stromal compartment, combined with urothelial cells, for the epithelial compartment [280-282]. Adipose stromal tissue can be produced with a self-assembly method using adipose-derived stem cells (ASCs) [283]. ASCs have osteogenic potential. In recent years, a thin bone substitute has been produced using osteocytes with the self-assembly method [284]. ASCs also demonstrated the potential to produce blood vessels and treat scars; they have also been used to improve bladder tissues [285-287]. Vaginal mucosa could also be made with the self-assembly method using organ-specific cells [288].

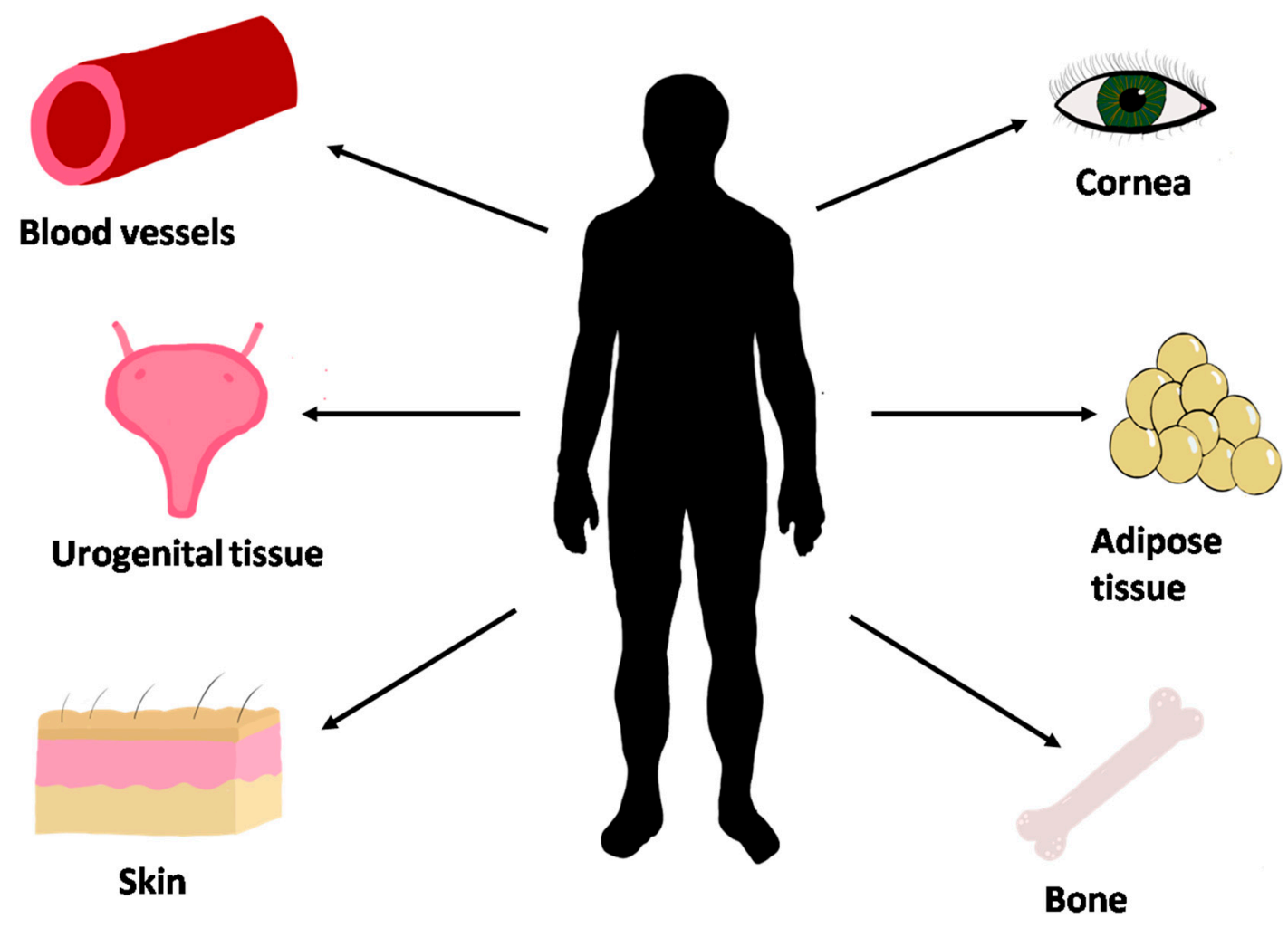

Figure 7. Types of tissues that can be reconstructed by tissue engineering using the self-assembly technique developed at LOEX.

Table 3. Advantages and disadvantages of basic self-assembly techniques compared with common methods in tissue engineering.

\begin{tabular}{cc}
\hline Advantages & Disadvantages \\
\hline No need of scaffold: no immune or other reaction associated with the graft & Expensive \\
\hline Good mechanical strength of the reconstruct tissue & The technique is more complicated \\
\hline Reconstruct tissue present histologically similar to the native tissue & Longer than other techniques \\
\hline
\end{tabular}




\section{Applications of 3D Cell Cultures}

\subsection{Pathology}

Various models to study specific pathologies have been developed using the self-assembly approach, thus contributing to enhance personalized medicine and reduce animal testing.

For instance, 3D in vitro psoriatic skin models that successfully demonstrate psoriasis characteristics, like excessive proliferation and abnormal differentiation of keratinocytes, have been developed by Jean and collaborators using cells derived from patients with psoriasis [71]. The model, made by the self-assembly method, has been used in studies that aim at better defining cellular events of the pathology or characterize specific distinctions of psoriatic skin [65,72]. Skin fibrosis was also a selected pathology to be investigated using the self-assembly protocols, especially hypertrophic scars [289] and scleroderma [290,291]. The same protocol was used to study amyotrophic lateral sclerosis (ALS). Those constructs made from ALS patients' biopsies led to the identification of disease-specific biomarkers that can potentially be used as an early diagnosis tool of the disease [74]. In addition, various self-assembled 3D stromal tissues have been successfully used to study cancers [96]. The tumour microenvironments of skin and bladder cancers have been replicated adequately by this approach $[63,64]$. The use of these two cancer models for drug testing shows the potential to reduce the need for animal testing. The bladder mucosa model has also been used to study cystitis induced by ketamine use [292].

\subsection{Pharmacology}

The road to the development of a new drug is very long and expensive. It takes approximately 13.5 years to develop and market a drug and costs 1.8 billion US. However, only 7 to $11 \%$ of the developed drugs will be commercialized [5]. Animal models were used and are still being used today for drug development. For pharmaceutical research, 2D and 3D cell cultures represent an attractive alternative to animal models. Besides the advantages presented above, cell cultures offer the possibility to develop a personalized drug by using the patient's cells. Personalized therapy is beneficial for cancer patients since each tumour is different [293].

Cell culture is also beneficial for high-throughput screening (HTS) in drug discovery and characterization. HTS is a process developed in the 1990s from the fruitful wedding of combinatory chemistry and automation of techniques [294]. The goal of HTS is to screen a library containing a large number of potentially active molecules against a specific target to find the best potential drug. HTS could be used to discover a new drug or characterize its toxicology or metabolism [295]. With cell cultures, absorption, distribution, metabolism, excretion, and toxicity of a drug could be elucidated at the beginning of drug development and not in preclinical, i.e., on animals, or in clinical trials [294]. Cell-based HTS could reduce the number of animals used in research and reduce the cost and time of the development of a drug.

Drugs can be tested on 2D cell cultures, but monolayer cell culture has some limitations, as presented above. One of the significant flaws in the 2D cell culture is that it could not reflect the drug's effect on the architecture of the tissue and cell-cell adhesion [107]. Indeed, cells in 3D cultures produce extracellular matrix (ECM), which is not produced by cells in 2D cells. ECM contains many components, such as growth factors, glycosaminoglycans, proteoglycans, and matrix proteins [110]. These factors regulate important cellular mechanisms such as cell proliferation, cell adhesion, cytoskeletal rearrangement, and many more [110]. A drug could interact with ECM components and modify some cell mechanisms. Interaction of the drug with ECM components would not be similar on a $2 \mathrm{D}$ than a 3D cell culture because there are not the same ECM components in a 2D cell culture.

On the other hand, these interactions could be studied on 3D cell cultures. Cells do not interact only with ECM in vitro, but they also interact with stromal cells such as fibroblast, adipocyte, and glial cells [110]. Interactions between cells can influence the drug response in vitro. For example, 
the interaction between the tumour and the stromal cell is the cause of many cases of drug resistance [296]. Once again, this phenomenon would not be observed in 2D cell cultures but could be in 3D cell cultures, as 3D cell culture reproduces more accurately the environment of the native tissue [110].

In recent years, many studies have been done on drug discovery and drug response for cancer treatment using 3D cell culture. For example, in 2018, a team from Columbia University tested drug response on organoids made from bladder cancer tumours. They isolated 16 tumour cell lines from individual patients, and 40 compounds were tested on nine organoids cell lines, and ten more compounds were tested on nine cell lines. These compounds contained molecules as trametinib, Erlotinib, and Ganetespid. Different drug responses were obtained with the drug screening depending on the cell lines. Some of these potential molecules were tested on xenograft in mice to validate drug response, and the same response was obtained in organoids and in vivo [297]. This method allows screening of components to find the most convenient drug for patients. Furthermore, instead, to test a large number of compounds on mice, only the ones that were promising on the organoid drug screening were tested on the animal model. This technique could reduce the number of mice that are used for drug testing, and maybe, in the future, if 3D cell culture improvements are sufficient, the step of testing the drug on an animal could be eliminated.

Nevertheless, 3D cell cultures in pharmaceutical research have some limitations. First, the experiments can be difficult to reproduce due to the heterogeneity of the cell population from the patient, but several works are in progress to improve this point. In addition, 3D cell culture is more expensive when compared with 2D cell cultures [53].

\section{Perspectives}

\subsection{Serum-Free Medium}

As an improvement of the current 3D culture methods, more research has been made to eliminate the use of serum in the culture medium. Fetal bovine serum (FBS) has been used for a long time as the ultimate supplement in culture media of human and animal cells due to its ubiquity. It contains various essential components, such as hormones, vitamins, proteins, growth factors, and traces of elements to sustain proper cell proliferation. FBS is extracted from the blood harvested by a syringe placed through the beating heart of cow fetuses at any developmental stage of the last two-thirds of gestation. These fetuses are mostly discovered by accident during the slaughter of pregnant cows. Developing a serum-free medium with the same properties as FBS would reduce animal use in research, as dictated by the $3 R$ principles.

Many issues can be observed with the use of FBS in cell culture. First, it was shown that cow fetuses experienced pain and distress during the harvesting of their blood for FBS production, which raises ethical concerns [298]. Moreover, the exact composition of FBS is unknown and varies from lot-to-lot. This can lead to impaired cell differentiation and low experimental reproducibility [108]. Moreover, unintended interactions with tested substances are a possible risk. Safety concerns have been raised for laboratory personnel in terms of a possible exposition to endotoxins, mycoplasma, viral contaminants, and prions proteins [298]. Finally, FBS is an expensive product. Developing a cheaper alternative could be beneficial to lower experiment costs, particularly for small laboratories.

A universal synthetic medium replacing FBS has not been developed so far, but progress has been made in developing a specific serum-free differentiation medium. For instance, A.C. Volz and P.J. Kluger have achieved the differentiation of human adipose tissue-derived stem cells into adipocytes using a serum-free medium [299]. M. Fakhr Taha and collaborators have differentiated adipose tissue-derived stem cells into dopaminergic neurons in culture with a serum-free medium, with better results than their conventional low-serum medium [300]. 


\subsection{Immune System}

Recently, to improve 3D models to be used to replace animal models, several efforts have been made to include immune components into these models. Immunocompetent 3D skin models have been described [301] and recently, a psoriatic skin model has been refined by the addition of T cells [302]. Three-dimensional immunocompetent organ-on-chip models have also been explored to produce a more accurate model, at least in part, to replace animal models [303].

\subsection{Connection between Organs through Vascularization}

As was done for microfluidics [272], the connection between reconstructed tissues through a vascular system can mimic the interaction between organs. Blood vessels can easily be reconstructed using the self-assembly method [304]. These vessels can be connected with the pseudo-capillary network present inside the tissue, as it does after tissue-grafting in vivo [305-308]. Using several different techniques, functional three-dimensional tissues with perfusable blood vessels can be fabricated in vitro [309-311].

\subsection{Combination of Techniques of Production and Maturation}

Recently, the combination of several techniques of production or maturation, such as induced pluripotent stem cells, organoids, bioprinting, composite hydrogels, organ-on-chip, microphysiological systems, mechanical stimuli, innervation etc., (e.g., [312-316]), gave us the opportunity to produce a large spectra of complex organs. These organs could also be used for various applications such as potential transplantation (e.g., [317]) or disease modeling (e.g., [318-320]). For example, after demonstrating the functionality of hepatic cells bioprinted on collagen gels to drug screening [321], a mini-liver was produced using iPSC which differentiated into hepatocyte and self-organized into acini [322]. The basis of the production of liver substitute for transplantation has been laid: such a tissue required not only the right differentiation and organization of hepatocyte but also irrigation by a vascular network and potential reconnection to the host [317]. Another example: a gut-on-chip platform has been established to study various physiological aspect of this complex organ which is the gastrointestinal tract [323].

\section{Conclusions}

Even though all the methods used in TE to build tissue constructs were not primarily developed for research purposes, these techniques, by their various properties, allow scientists to produce reliable models of human tissues, organs, and pathologies. By their accuracy, these models significantly reduce the need to use animal models as research tools, thereby respecting the $3 \mathrm{R}$ principles. Depending on the method used, some improvements still need to be made to eliminate all use of animal-derived materials in TE, but 3D cultures can be considered viable ethical alternatives.

Author Contributions: Writing—original draft preparation, P.B., S.G. and K.F.; writing-review and editing, P.B., S.G., K.F., C.C., È.P., S.C. and S.B.; supervision, S.B.; funding acquisition, S.B. All authors have read and agreed to the published version of the manuscript.

Funding: This research was funded by a Canadian Urological Association Scholarship (S.B.), a Canadian Institutes of Health Research Grant (\#258229) (S.B.), and the Quebec Cell, Tissue and Gene Therapy Network-ThéCell (a thematic network supported by the Fonds de recherche du Québec-Santé).

Conflicts of Interest: The authors declare no conflict of interest.

\section{References}

1. Ericsson, A.C.; Crim, M.J.; Franklin, C.L. A brief history of animal modeling. Mo. Med. 2013, 110, $201-205$. [PubMed]

2. Gore, A.V.; Pillay, L.M.; Venero Galanternik, M.; Weinstein, B.M. The zebrafish: A fintastic model for hematopoietic development and disease. Wiley Interdiscip. Rev. Dev. Biol. 2018, 7, e312. [CrossRef] [PubMed] 
3. Pérez-Guijarro, E.; Day, C.-P.; Merlino, G.; Zaidi, M.R. Genetically engineered mouse models of melanoma. Cancer 2017, 123, 2089-2103. [CrossRef] [PubMed]

4. Hoogenboom, W.S.; Klein Douwel, D.; Knipscheer, P. Xenopus egg extract: A powerful tool to study genome maintenance mechanisms. Dev. Biol. 2017, 428, 300-309. [CrossRef] [PubMed]

5. Nicolaou, K.C. Advancing the drug discovery and development process. Angew. Chem. Int. Ed. 2014, 53, 9128-9140. [CrossRef] [PubMed]

6. Parkinson, C.; Grasso, P. The use of the dog in toxicity tests on pharmaceutical compounds. Hum. Exp. Toxicol. 1993, 12, 99-109. [CrossRef]

7. Tolwinski, N. Introduction: Drosophila-A model system for developmental biology. J. Dev. Biol. 2017 , 5, 9. [CrossRef]

8. Lieschke, G.J.; Currie, P.D. Animal models of human disease: Zebrafish swim into view. Nat. Rev. Genet. 2007, 8, 353-367. [CrossRef]

9. Blum, M.; Ott, T. Xenopus: An undervalued model organism to study and model human genetic disease. Cells Tissues Organs 2018, 205, 303-313. [CrossRef]

10. United States Department of Agriculture. Animal and Plant Health Inspection Service. Annual Report Animal Usage by Fiscal Year; United States Department of Agriculture: Washington, DC, USA, 2020.

11. Vandamme, T.F. Rodent models for human diseases. Eur. J. Pharmacol. 2015, 759, 84-89. [CrossRef]

12. Rocha-Martins, M.; Cavalheiro, G.R.; Matos-Rodrigues, G.E.; Martins, R.A.P. From Gene targeting to genome editing: Transgenic animals applications and beyond. An. Acad. Bras. Ciências 2015, 87, 1323-1348. [CrossRef]

13. Demetrius, L. Aging in mouse and human systems: A comparative study. Ann. N. Y. Acad. Sci. 2006, 1067, 66-82. [CrossRef] [PubMed]

14. Filipiak, W.E.; Saunders, T.L. Advances in transgenic rat production. Transgenic Res. 2006, 15, 673-686. [CrossRef] [PubMed]

15. Cho, S.J.; Bang, J.I.; Yu, X.F.; Lee, Y.S.; Kim, J.H.; Jeon, J.T.; Yee, S.T.; Kong, I.K. Generation of a recloned transgenic cat expressing red fluorescence protein. Theriogenology 2010, 73, 848-855. [CrossRef]

16. Lang, C.N.; Koren, G.; Odening, K.E. Transgenic rabbit models to investigate the cardiac ion channel disease long QT syndrome. Prog. Biophys. Mol. Biol. 2016, 121, 142-156. [CrossRef]

17. Andersen, M.L.; Winter, L.M.F. Animal models in biological and biomedical research-experimental and ethical concerns. An. Acad. Bras. Ciências 2019, 91. [CrossRef]

18. Karamanou, M. Milestones in the history of diabetes mellitus: The main contributors. World J. Diabetes 2016, 7, 1. [CrossRef]

19. Russell, W.M.S.; Burch, R.L. The Principles of Humane Experimental Technique; Methuen \& Co. Limited: London, UK, 1959.

20. Macarthur, C.J. The 3Rs in research: A contemporary approach to replacement, reduction and refinement. Br. J. Nutr. 2018, 120, S1-S7. [CrossRef]

21. Mather, J.A. Ethics and care: For animals, not just mammals. Animals 2019, 9, 1018. [CrossRef]

22. Olson, H.; Betton, G.; Robinson, D.; Thomas, K.; Monro, A.; Kolaja, G.; Lilly, P.; Sanders, J.; Sipes, G.; Bracken, W.; et al. Concordance of the toxicity of pharmaceuticals in humans and in animals. Regul. Toxicol. Pharm. 2000, 32, 56-67. [CrossRef]

23. Greek, R.; Menache, A. Systematic reviews of animal models: Methodology versus epistemology. Int. J. Med. Sci. 2013, 10, 206-221. [CrossRef] [PubMed]

24. Denayer, T.; Stöhr, T.; Roy, M.V. Animal models in translational medicine: Validation and prediction. Eur. J. Mol. Clin. Med. 2014, 2. [CrossRef]

25. Collins, F.S.; Tabak, L.A. Policy: NIH plans to enhance reproducibility. Nature 2014, 505, 612-613. [CrossRef]

26. Sápi, J. Animal experiments in cancer research: Wasteful or unavoidable? In Proceedings of the 2017 IEEE 30th Neumann Colloquium (NC), Budapest, Hungary, 24 November 2017; pp. 157-162. [CrossRef]

27. Barnard, N.D.; Kaufman, S.R. Animal research is wasteful and misleading. Sci. Am. 1997, $276,80-82$. [CrossRef]

28. Bailey, J. An assessment of the role of chimpanzees in AIDS vaccine research. Altern. Lab. Anim. 2008, 36, 381-428. [CrossRef]

29. Mak, I.W.; Evaniew, N.; Ghert, M. Lost in translation: Animal models and clinical trials in cancer treatment. Am. J. Transl. Res. 2014, 6, 114-118. [PubMed] 
30. Chu, C.R.; Szczodry, M.; Bruno, S. Animal models for cartilage regeneration and repair. Tissue Eng. Part B Rev. 2010, 16, 105-115. [CrossRef]

31. Meigs, L. Animal testing and its alternatives-The most important omics is economics. ALTEX 2018, 275-305. [CrossRef]

32. Doke, S.K.; Dhawale, S.C. Alternatives to animal testing: A review. Saudi Pharm. J. 2015, 23, 223-229. [CrossRef]

33. National Research Council Committee on Recognition and Alleviation of Pain in Laboratory Animals. The national academies collection: Reports funded by national institutes of health. In Recognition and Alleviation of Pain in Laboratory Animals; National Academies Press: Washington, DC, USA, 2009. [CrossRef]

34. European Commission. Reach in Brief; Environment Directorate General: Brussels, Belgium, 2007; p. 19.

35. Lee, M.; Hwang, J.H.; Lim, K.M. Alternatives to in vivo draize rabbit eye and skin irritation tests with a focus on 3D reconstructed human cornea-like epithelium and epidermis models. Toxicol. Res. 2017, 33, 191-203. [CrossRef] [PubMed]

36. Langford, D.J.; Bailey, A.L.; Chanda, M.L.; Clarke, S.E.; Drummond, T.E.; Echols, S.; Glick, S.; Ingrao, J.; Klassen-Ross, T.; Lacroix-Fralish, M.L.; et al. Coding of facial expressions of pain in the laboratory mouse. Nat. Methods 2010, 7, 447-449. [CrossRef] [PubMed]

37. Smith, A.J. Guidelines for planning and conducting high-quality research and testing on animals. Lab. Anim. Res. 2020, 36, 21. [CrossRef] [PubMed]

38. Sloman, K.A.; Bouyoucos, I.A.; Brooks, E.J.; Sneddon, L.U. Ethical considerations in fish research. J. Fish Biol. 2019, 94, 556-577. [CrossRef] [PubMed]

39. Price, P.J. Best practices for media selection for mammalian cells. In Vitro Cell. Dev. Biol. Anim. 2017, 53, 673-681. [CrossRef]

40. Feretti, D.; Zerbini, I.; Zani, C.; Ceretti, E.; Moretti, M.; Monarca, S. Allium cepachromosome aberration and micronucleus tests applied to study genotoxicity of extracts from pesticide-treated vegetables and grapes. Food Addit. Contam. 2007, 24, 561-572. [CrossRef]

41. Kristen, U.; Friedrich, R.E. Toxicity screening of mouthwashes in the pollen tube growth test: Safety assessment of recommended dilutions. Braz. Dent. J. 2006, 17, 58-62. [CrossRef]

42. Arora, T.A.K.M.; Joshi, V.K.D.M.; Rathor, N.; Mediratta, P.K.; Sharma, K.K. Substitute of animals in drug research: An approach towards fulfillment of 4R's. Indian J. Pharm. Sci. 2011, 73, 1-6. [CrossRef]

43. Eki, T. Yeast-based genotoxicity tests for assessing DNA alterations and DNA stress responses: A 40-year overview. Appl. Microbiol. Biotechnol. 2018, 102, 2493-2507. [CrossRef]

44. Ekins, S.; Mestres, J.; Testa, B. In silicopharmacology for drug discovery: Methods for virtual ligand screening and profiling. Br. J. Pharmacol. 2007, 152, 9-20. [CrossRef]

45. Hartung, T.; Hoffmann, S. Food for thought on in silico methods in toxicology. ALTEX 2009, 155-166. [CrossRef]

46. Jedrzejczak-Silicka, M. History of cell culture. In New Insights into Cell Culture Technology; IntechOpen Limited: London, UK, 2017. [CrossRef]

47. Duval, K.; Grover, H.; Han, L.H.; Mou, Y.; Pegoraro, A.F.; Fredberg, J.; Chen, Z. Modeling physiological events in 2D vs. 3D cell culture. Physiology 2017, 32, 266-277. [CrossRef] [PubMed]

48. Saji Joseph, J.; Tebogo Malindisa, S.; Ntwasa, M. Two-Dimensional (2D) and Three-Dimensional (3D) cell culturing in drug discovery. Cell Cult. 2019. [CrossRef]

49. Cukierman, E.; Pankov, R.; Stevens, D.R.; Yamada, K.M. Taking cell-matrix adhesions to the third dimension. Science 2001, 294, 1708-1712. [CrossRef] [PubMed]

50. Sundarakrishnan, A.; Chen, Y.; Black, L.D.; Aldridge, B.B.; Kaplan, D.L. Engineered cell and tissue models of pulmonary fibrosis. Adv. Drug Deliv. Rev. 2018, 129, 78-94. [CrossRef] [PubMed]

51. Shamir, E.R.; Ewald, A.J. Three-dimensional organotypic culture: Experimental models of mammalian biology and disease. Nat. Rev. Mol. Cell Biol. 2014, 15, 647-664. [CrossRef]

52. Birgersdotter, A.; Sandberg, R.; Ernberg, I. Gene expression perturbation in vitro-a growing case for three-dimensional (3D) culture systems. Semin. Cancer Biol. 2005, 15, 405-412. [CrossRef]

53. Edmondson, R.; Broglie, J.J.; Adcock, A.F.; Yang, L. Three-dimensional cell culture systems and their applications in drug discovery and cell-based biosensors. Assay Drug Dev. Technol. 2014, 12, 207-218. [CrossRef]

54. Ashe, H.L. The interpretation of morphogen gradients. Development 2006, 133, 385-394. [CrossRef] 
55. Hoarau-Véchot, J.; Rafii, A.; Touboul, C.; Pasquier, J. Halfway between 2D and animal models: Are 3D cultures the ideal tool to study cancer-microenvironment interactions? Int. J. Mol. Sci. 2018, 19, 181. [CrossRef]

56. Pebworth, M.P.; Cismas, S.A.; Asuri, P. A novel 2.5D culture platform to investigate the role of stiffness gradients on adhesion-independent cell migration. PLoS ONE 2014, 9, e110453. [CrossRef]

57. de la Zerda, A.; Kratochvil, M.J.; Suhar, N.A.; Heilshorn, S.C. Review: Bioengineering strategies to probe T cell mechanobiology. APL Bioeng. 2018, 2, 021501. [CrossRef] [PubMed]

58. Huh, D.; Hamilton, G.A.; Ingber, D.E. From 3D cell culture to organs-on-chips. Trends Cell Biol. 2011, 21, 745-754. [CrossRef] [PubMed]

59. Pruniéras, M.; Delescluse, C.; Regnier, M. The culture of skin a review of theories and experimental methods. J. Investig. Dermatol. 1976, 67, 58-65. [CrossRef] [PubMed]

60. Castro, N.; Gillespie, S.R.; Bernstein, A.M. Ex vivo corneal organ culture model for wound healing studies. J. Vis. Exp. 2019. [CrossRef]

61. Levenberg, S. Engineering blood vessels from stem cells: Recent advances and applications. Curr. Opin. Biotechnol. 2005, 16, 516-523. [CrossRef]

62. Frieboes, H.B.; Zheng, X.; Sun, C.H.; Tromberg, B.; Gatenby, R.; Cristini, V. An integrated computational/ experimental model of tumor invasion. Cancer Res. 2006, 66, 1597-1604. [CrossRef]

63. Friedrich, J.; Seidel, C.; Ebner, R.; Kunz-Schughart, L.A. Spheroid-based drug screen: Considerations and practical approach. Nat. Protoc. 2009, 4, 309-324. [CrossRef]

64. Bonnier, F.; Keating, M.E.; Wrobel, T.P.; Majzner, K.; Baranska, M.; Garcia-Munoz, A.; Blanco, A.; Byrne, H.J. Cell viability assessment using the Alamar blue assay: A comparison of 2D and 3D cell culture models. Toxicol. In Vitro 2015, 29, 124-131. [CrossRef]

65. Jean, J.; Lapointe, M.; Soucy, J.; Pouliot, R. Development of an in vitro psoriatic skin model by tissue engineering. J. Dermatol. Sci. 2009, 53, 19-25. [CrossRef]

66. Paré, B.; Touzel-Deschênes, L.; Lamontagne, R.; Lamarre, M.-S.; Scott, F.-D.; Khuong, H.T.; Dion, P.A.; Bouchard, J.-P.; Gould, P.; Rouleau, G.A.; et al. Early detection of structural abnormalities and cytoplasmic accumulation of TDP-43 in tissue-engineered skins derived from ALS patients. Acta Neuropathol. Commun. 2015, 3. [CrossRef]

67. Ringuette Goulet, C.; Bernard, G.; Chabaud, S.; Couture, A.; Langlois, A.; Neveu, B.; Pouliot, F.; Bolduc, S. Tissue-engineered human 3D model of bladder cancer for invasion study and drug discovery. Biomaterials 2017, 145, 233-241. [CrossRef] [PubMed]

68. Bourland, J.; Fradette, J.; Auger, F.A. Tissue-engineered 3D melanoma model with blood and lymphatic capillaries for drug development. Sci. Rep. 2018, 8. [CrossRef]

69. Karlsson, H.; Fryknäs, M.; Larsson, R.; Nygren, P. Loss of cancer drug activity in colon cancer HCT-116 cells during spheroid formation in a new 3-D spheroid cell culture system. Exp. Cell Res. 2012, 318, 1577-1585. [CrossRef]

70. Jetten, A.M. Growth and differentiation factors in tracheobronchial epithelium. Am. J. Physiol. 1991, 260, L361-L373. [CrossRef]

71. Gray, T.; Rundhaug, J.; Nettesheim, P. Critical variables controlling cell proliferation in primary cultures of rat tracheal epithelial cells. In Vitro Cell. Dev. Biol. 1991, 27, 805-814. [CrossRef]

72. García-Pérez, M.-E.; Royer, M.; Duque-Fernandez, A.; Diouf, P.N.; Stevanovic, T.; Pouliot, R. Antioxidant, toxicological and antiproliferative properties of Canadian polyphenolic extracts on normal and psoriatic keratinocytes. J. Ethnopharmacol. 2010, 132, 251-258. [CrossRef]

73. Jean, J.; Leroy, M.; Duque-Fernandez, A.; Bernard, G.; Soucy, J.; Pouliot, R. Characterization of a psoriatic skin model produced with involved or uninvolved cells. J. Tissue Eng. Regen. Med. 2015, 9, 789-798. [CrossRef] [PubMed]

74. Jean, J.; Soucy, J.; Pouliot, R. Effects of retinoic acid on keratinocyte proliferation and differentiation in a psoriatic skin model. Tissue Eng. Part A 2011, 17, 1859-1868. [CrossRef]

75. Ayata, R.E.; Bouhout, S.; Auger, M.; Pouliot, R. Study of in vitro capillary-like structures in psoriatic skin substitutes. Biores. Open Access 2014, 3, 197-205. [CrossRef]

76. Boneva, R.S.; Folks, T.M.; Chapman, L.E. Infectious disease issues in xenotransplantation. Clin. Microbiol. Rev. 2001, 14, 1-14. [CrossRef] 
77. Murphy, F.A. The public health risk of animal organ and tissue transplantation into humans. Science 1996, 273, 746-747. [CrossRef]

78. Bolduc, S. Surgical correction of genitourinary disorders using the self-assembly tissue engineering. Int. J. Regen. Med. 2019. [CrossRef]

79. Shinoka, T.; Shum-Tim, D.; Ma, P.X.; Tanel, R.E.; Isogai, N.; Langer, R.; Vacanti, J.P.; Mayer, J.E. Creation of viable pulmonary artery autografts through tissue engineering. J. Thorac. Cardiovasc. Surg. 1998, 115, 536-546. [CrossRef]

80. Gstraunthaler, G.; Lindl, T.; van der Valk, J. A plea to reduce or replace fetal bovine serum in cell culture media. Cytotechnology 2013, 65, 791-793. [CrossRef]

81. Van Der Valk, J. Fetal bovine serum (FBS): Past-Present-Future. ALTEX 2018, 99-118. [CrossRef]

82. Price, P.J.; Gregory, E.A. Relationship between in vitro growth promotion and biophysical and biochemical properties of the serum supplement. In Vitro 1982, 18, 576-584. [CrossRef]

83. Breslin, S.; O'Driscoll, L. Three-dimensional cell culture: The missing link in drug discovery. Drug Discov. Today 2013, 18, 240-249. [CrossRef]

84. Schmal, O.; Seifert, J.; Schäffer, T.E.; Walter, C.B.; Aicher, W.K.; Klein, G. Hematopoietic stem and progenitor cell expansion in contact with mesenchymal stromal cells in a hanging drop model uncovers disadvantages of 3D culture. Stem Cells Int. 2016, 2016, 4148093. [CrossRef]

85. Moghadas, H.; Saidi, M.S.; Kashaninejad, N.; Kiyoumarsioskouei, A.; Nguyen, N.-T. Fabrication and characterization of low-cost, bead-free, durable and hydrophobic electrospun membrane for 3D cell culture. Biomed. Microdevices 2017, 19. [CrossRef]

86. Khalil, S.; El-Badri, N.; El-Mokhtaar, M.; Al-Mofty, S.; Farghaly, M.; Ayman, R.; Habib, D.; Mousa, N. A cost-effective method to assemble biomimetic 3D cell culture platforms. PLoS ONE 2016, 11, e0167116. [CrossRef]

87. Joshi, P.; Lee, M.-Y. High Content Imaging (HCI) on miniaturized Three-Dimensional (3D) cell cultures. Biosensors 2015, 5, 768-790. [CrossRef] [PubMed]

88. Fröhlich, E. Comparison of conventional and advanced in vitro models in the toxicity testing of nanoparticles. Artif. Cells Nanomed. Biotechnol. 2018, 46, 1091-1107. [CrossRef] [PubMed]

89. Rimann, M.; Graf-Hausner, U. Synthetic 3D multicellular systems for drug development. Curr. Opin. Biotechnol. 2012, 23, 803-809. [CrossRef] [PubMed]

90. Aijian, A.P.; Garrell, R.L. Digital microfluidics for automated hanging drop cell spheroid culture. J. Lab. Autom. 2015, 20, 283-295. [CrossRef]

91. Kelm, J.M.; Timmins, N.E.; Brown, C.J.; Fussenegger, M.; Nielsen, L.K. Method for generation of homogeneous multicellular tumor spheroids applicable to a wide variety of cell types. Biotechnol. Bioeng. 2003, 83, 173-180. [CrossRef]

92. Djomehri, S.I.; Burman, B.; Gonzalez, M.E.; Takayama, S.; Kleer, C.G. A reproducible scaffold-free 3D organoid model to study neoplastic progression in breast cancer. J. Cell Commun. Signal. 2019, 13, 129-143. [CrossRef]

93. Boyce, S.T. Cultured skin substitutes: A review. Tissue Eng. 1996, 2, 255-266. [CrossRef]

94. Imbeault, A.; Bernard, G.; Ouellet, G.; Bouhout, S.; Carrier, S.; Bolduc, S. Surgical option for the correction of peyronie's disease: An autologous tissue-engineered endothelialized graft. J. Sex. Med. 2011, 8, 3227-3235. [CrossRef]

95. Tremblay, P.-L.; Hudon, V.; Berthod, F.; Germain, L.; Auger, F.A. Inosculation of tissue-engineered capillaries with the host's vasculature in a reconstructed skin transplanted on mice. Am. J. Transplant. 2005, 5, 1002-1010. [CrossRef]

96. Roy, V.; Magne, B.; Vaillancourt-Audet, M.; Blais, M.; Chabaud, S.; Grammond, E.; Piquet, L.; Fradette, J.; Laverdière, I.; Moulin, V.J.; et al. Human organ-specific 3D cancer models produced by the stromal self-assembly method of tissue engineering for the study of solid tumors. BioMed Res. Int. 2020, 2020, 6051210. [CrossRef]

97. Lee, J.W.; Choi, Y.J.; Yong, W.J.; Pati, F.; Shim, J.H.; Kang, K.S.; Kang, I.H.; Park, J.; Cho, D.W. Development of a 3D cell printed construct considering angiogenesis for liver tissue engineering. Biofabrication 2016, 8. [CrossRef] [PubMed]

98. Martin, I.; Simmons, P.J.; Williams, D.F. Manufacturing challenges in regenerative medicine. Sci. Transl. Med. 2014, 6. [CrossRef] [PubMed] 
99. Keire, P.A.; L'Heureux, N.; Vernon, R.B.; Merrilees, M.J.; Starcher, B.; Okon, E.; Dusserre, N.; McAllister, T.N.; Wight, T.N. Expression of versican isoform V3 in the absence of ascorbate improves elastogenesis in engineered vascular constructs. Tissue Eng. Part A 2010, 16, 501-512. [CrossRef]

100. Bishop, E.S.; Mostafa, S.; Pakvasa, M.; Luu, H.H.; Lee, M.J.; Wolf, J.M.; Ameer, G.A.; He, T.-C.; Reid, R.R. 3-D bioprinting technologies in tissue engineering and regenerative medicine: Current and future trends. Genes Dis. 2017, 4, 185-195. [CrossRef]

101. Turnbull, G.; Clarke, J.; Picard, F.; Riches, P.; Jia, L.; Han, F.; Li, B.; Shu, W. 3D bioactive composite scaffolds for bone tissue engineering. Bioact. Mater. 2018, 3, 278-314. [CrossRef]

102. Filippi, M.; Born, G.; Chaaban, M.; Scherberich, A. Natural polymeric scaffolds in bone regeneration. Front. Bioeng. Biotechnol. 2020, 8, 474. [CrossRef] [PubMed]

103. Kucinska, M.; Murias, M.; Nowak-Sliwinska, P. Beyond mouse cancer models: Three-dimensional human-relevant in vitro and non-mammalian in vivo models for photodynamic therapy. Mutat. Res. Rev. Mutat. Res. 2017, 773, 242-262. [CrossRef]

104. Worthington, P.; Pochan, D.J.; Langhans, S.A. Peptide hydrogels-Versatile matrices for 3D cell culture in cancer medicine. Front. Oncol. 2015, 5, 92. [CrossRef] [PubMed]

105. Chaudhari, A.A.; Vig, K.; Baganizi, D.R.; Sahu, R.; Dixit, S.; Dennis, V.; Singh, S.R.; Pillai, S.R. Future prospects for scaffolding methods and biomaterials in skin tissue engineering: A review. Int. J. Mol. Sci. 2016, 17, 1974. [CrossRef]

106. Chaicharoenaudomrung, N.; Kunhorm, P.; Noisa, P. Three-dimensional cell culture systems as an in vitro platform for cancer and stem cell modeling. World J. Stem Cells 2019, 11, 1065-1083. [CrossRef]

107. Fang, Y.; Eglen, R.M. Three-dimensional cell cultures in drug discovery and development. SLAS Discov. 2017, 22, 456-472. [CrossRef]

108. Saba, I.; Jakubowska, W.; Bolduc, S.; Chabaud, S. Engineering tissues without the use of a synthetic scaffold: A twenty-year history of the self-assembly method. BioMed Res. Int. 2018, 2018, 5684679. [CrossRef]

109. Ovsianikov, A.; Khademhosseini, A.; Mironov, V. The synergy of scaffold-based and scaffold-free tissue engineering strategies. Trends Biotechnol. 2018, 36, 348-357. [CrossRef] [PubMed]

110. Langhans, S.A. Three-Dimensional in vitro cell culture models in drug discovery and drug repositioning. Front. Pharmacol. 2018, 9, 6. [CrossRef]

111. Ravi, M.; Paramesh, V.; Kaviya, S.R.; Anuradha, E.; Paul Solomon, F.D. 3D cell culture systems: Advantages and applications. J. Cell. Physiol. 2015, 230, 16-26.

112. Yunus Basha, R.; Sampath Kumar, T.S.; Doble, M. Design of biocomposite materials for bone tissue regeneration. Mater. Sci. Eng. C Mater. Biol. Appl. 2015, 57, 452-463. [CrossRef]

113. Reddy, R.; Reddy, N. Biomimetic approaches for tissue engineering. J. Biomater. Sci. Polym. Ed. 2018, 29, 1667-1685. [CrossRef]

114. de la Puente, P.; Ludeña, D. Cell culture in autologous fibrin scaffolds for applications in tissue engineering. Exp. Cell Res. 2014, 322, 1-11. [CrossRef]

115. Chen, G.; Kawazoe, N. Porous scaffolds for regeneration of cartilage, bone and osteochondral tissue. Adv. Exp. Med. Biol. 2018, 1058, 171-191. [CrossRef]

116. Burunkova, J.; Denisiuk, I.; Vorzobova, N.; Daroczi, L.; Hegedus, C.; Charnovych, S.; Kokenyesi, S. Fabrication and characterization of gold/acrylic polymer nanocomposites. Eur. Polym. J. 2013, 49, 3072-3077. [CrossRef]

117. Murali, K.P.; Sharma, H.; Markondeya Raj, P.; Mishra, D.; Goyal, M.; Silver, K.; Shipton, E.; Tummala, R. Structure-magnetic property correlations in nickel-polymer nanocomposites. J. Mater. Sci. Mater. Electron. 2016, 27, 154-162. [CrossRef]

118. Zaferani, S.H. 1-Introduction of polymer-based nanocomposites. In Polymer-Based Nanocomposites for Energy and Environmental Applications; Jawaid, M., Khan, M.M., Eds.; Woodhead Publishing: Sawston, UK, 2018; pp. 1-25. [CrossRef]

119. Ahn, T.K.; Lee, D.H.; Kim, T.S.; Jang, G.C.; Choi, S.; Oh, J.B.; Ye, G.; Lee, S. Modification of titanium implant and titanium dioxide for bone tissue engineering. Adv. Exp. Med. Biol. 2018, 1077, 355-368. [CrossRef] [PubMed]

120. Yazdimamaghani, M.; Razavi, M.; Vashaee, D.; Moharamzadeh, K.; Boccaccini, A.R.; Tayebi, L. Porous magnesium-based scaffolds for tissue engineering. Mater. Sci. Eng. C 2017, 71, 1253-1266. [CrossRef] 
121. Kalita, H.; Pal, P.; Dhara, S.; Pathak, A. Fabrication and characterization of polyvinyl alcohol/metal (Ca, Mg, Ti) doped zirconium phosphate nanocomposite films for scaffold-guided tissue engineering application. Mater. Sci. Eng. C 2017, 71, 363-371. [CrossRef]

122. Yang, J.; Guo, J.L.; Mikos, A.G.; He, C.; Cheng, G. Material processing and design of biodegradable metal matrix composites for biomedical applications. Ann. Biomed. Eng. 2018, 46, 1229-1240. [CrossRef]

123. Lefebvre, L.P.; Banhart, J.; Dunand, D.C. Porous metals and metallic foams: Current status and recent developments. Adv. Eng. Mater. 2008, 10, 775-787. [CrossRef]

124. Yusop, A.H.; Bakir, A.A.; Shaharom, N.A.; Abdul Kadir, M.R.; Hermawan, H. Porous biodegradable metals for hard tissue scaffolds: A review. Int. J. Biomater. 2012, 2012, 641430. [CrossRef]

125. Van Hooreweder, B.; Apers, Y.; Lietaert, K.; Kruth, J.P. Improving the fatigue performance of porous metallic biomaterials produced by Selective Laser Melting. Acta Biomater. 2017, 47, 193-202. [CrossRef]

126. Hao, G.L.; Han, F.S.; Li, W.D. Processing and mechanical properties of magnesium foams. J. Porous Mater. 2009, 16, 251-256. [CrossRef]

127. Zhen, Z.; Xi, T.-F.; Zheng, Y.-F. A review on in vitro corrosion performance test of biodegradable metallic materials. Trans. Nonferr. Met. Soc. China 2013, 23, 2283-2293. [CrossRef]

128. Zhang, X.; Li, X.W.; Li, J.G.; Sun, X.D. Preparation and Mechanical Properties of a Novel Biomedical Magnesium-Based Scaffold. Key Eng. Mater. 2013, 544, 276-280. [CrossRef]

129. Körner, C.; Hirschmann, M.; Bräutigam, V.; Singer, R.F. Endogenous Particle Stabilization During Magnesium Integral Foam Production. Adv. Eng. Mater. 2004, 6, 385-390. [CrossRef]

130. Yamada, Y.; Shimojima, K.; Sakaguchi, Y.; Mabuchi, M.; Nakamura, M.; Asahina, T.; Mukai, T.; Kanahashi, H.; Higashi, K. Processing of an open-cellular AZ91 magnesium alloy with a low density of $0.05 \mathrm{~g} / \mathrm{cm}$. J. Mater. Sci. Lett. 1999, 18, 1477-1480. [CrossRef]

131. Renger, K.; Kaufmann, H. Vacuum foaming of magnesium slurries. Adv. Eng. Mater. 2005, 7, 117-123. [CrossRef]

132. Chen, T.; Hou, K.; Ren, Q.; Chen, G.; Wei, P.; Zhu, M. Nanoparticle-polymer synergies in nanocomposite hydrogels: From design to application. Macromol. Rapid Commun. 2018, 39. [CrossRef]

133. Karak, N. Chapter 1-Fundamentals of nanomaterials and polymer nanocomposites. In Nanomaterials and Polymer Nanocomposites; Karak, N., Ed.; Elsevier: Amsterdam, The Netherlands, 2019; pp. 1-45. [CrossRef]

134. Zare, Y.; Shabani, I. Polymer/metal nanocomposites for biomedical applications. Mater. Sci. Eng. C 2016, 60, 195-203. [CrossRef] [PubMed]

135. Dai, T.; Wang, C.; Wang, Y.; Xu, W.; Hu, J.; Cheng, Y. A nanocomposite hydrogel with potent and broad-spectrum antibacterial activity. ACS. Appl. Mater. Interfaces 2018, 10, 15163-15173. [CrossRef]

136. Son, W.K.; Youk, J.H.; Park, W.H. Antimicrobial cellulose acetate nanofibers containing silver nanoparticles. Carbohydr. Polym. 2006, 65, 430-434. [CrossRef]

137. Alavi, S.H.; Kheradvar, A. Metal mesh scaffold for tissue engineering of membranes. Tissue Eng. Part C Methods 2012, 18, 293-301. [CrossRef]

138. Wen, Y.; Xun, S.; Haoye, M.; Baichuan, S.; Peng, C.; Xuejian, L.; Kaihong, Z.; Xuan, Y.; Jiang, P.; Shibi, L. 3D printed porous ceramic scaffolds for bone tissue engineering: A review. Biomater. Sci. 2017, 5, 1690-1698. [CrossRef]

139. McLaren, E.A.; Whiteman, Y.Y. Ceramics: Rationale for material selection. Compend. Contin. Educ. Dent. 2010, 31, 666-668.

140. Ebrahimi, M.; Botelho, M.G.; Dorozhkin, S.V. Biphasic calcium phosphates bioceramics (HA/TCP): Concept, physicochemical properties and the impact of standardization of study protocols in biomaterials research. Mater. Sci. Eng. C 2017, 71, 1293-1312. [CrossRef]

141. Woodard, J.R.; Hilldore, A.J.; Lan, S.K.; Park, C.J.; Morgan, A.W.; Eurell, J.A.C.; Clark, S.G.; Wheeler, M.B.; Jamison, R.D.; Wagoner Johnson, A.J. The mechanical properties and osteoconductivity of hydroxyapatite bone scaffolds with multi-scale porosity. Biomaterials 2007, 28, 45-54. [CrossRef] [PubMed]

142. Bose, S.; Vahabzadeh, S.; Bandyopadhyay, A. Bone tissue engineering using 3D printing. Mater. Today 2013, 16, 496-504. [CrossRef]

143. Park, J.; Bauer, S.; von der Mark, K.; Schmuki, P. Nanosize and vitality: TiO2 nanotube diameter directs cell fate. Nano Lett. 2007, 7, 1686-1691. [CrossRef]

144. Karageorgiou, V.; Kaplan, D. Porosity of 3D biomaterial scaffolds and osteogenesis. Biomaterials 2005, 26, 5474-5491. [CrossRef] 
145. Rezwan, K.; Chen, Q.Z.; Blaker, J.J.; Boccaccini, A.R. Biodegradable and bioactive porous polymer/inorganic composite scaffolds for bone tissue engineering. Biomaterials 2006, 27, 3413-3431. [CrossRef]

146. Ma, H.; Feng, C.; Chang, J.; Wu, C. 3D-printed bioceramic scaffolds: From bone tissue engineering to tumor therapy. Acta Biomater. 2018, 79, 37-59. [CrossRef]

147. Wang, X.; Zhang, L.; Ke, X.; Wang, J.; Yang, G.; Yang, X.; He, D.; Shao, H.; He, Y.; Fu, J.; et al. $45 S 5$ Bioglass analogue reinforced akermanite ceramic favorable for additive manufacturing mechanically strong scaffolds. RSC Adv. 2015, 5, 102727-102735. [CrossRef]

148. Rainer, A.; Giannitelli, S.M.; Abbruzzese, F.; Traversa, E.; Licoccia, S.; Trombetta, M. Fabrication of bioactive glass-ceramic foams mimicking human bone portions for regenerative medicine. Acta Biomater. 2008, 4, 362-369. [CrossRef]

149. Mathieu, L.M.; Mueller, T.L.; Bourban, P.-E.; Pioletti, D.P.; Müller, R.; Månson, J.-A.E. Architecture and properties of anisotropic polymer composite scaffolds for bone tissue engineering. Biomaterials 2006, 27, 905-916. [CrossRef] [PubMed]

150. Li, X.; Feng, Q. Porous poly-L-lactic acid scaffold reinforced by chitin fibers. Polym. Bull. 2005, 54, 47-55. [CrossRef]

151. Cao, H.; Kuboyama, N. A biodegradable porous composite scaffold of PGA/ $\beta$-TCP for bone tissue engineering. Bone 2010, 46, 386-395. [CrossRef]

152. Bohner, M.; van Lenthe, G.H.; Grünenfelder, S.; Hirsiger, W.; Evison, R.; Müller, R. Synthesis and characterization of porous $\beta$-tricalcium phosphate blocks. Biomaterials 2005, 26, 6099-6105. [CrossRef]

153. Edgar, L.; McNamara, K.; Wong, T.; Tamburrini, R.; Katari, R.; Orlando, G. Heterogeneity of scaffold biomaterials in tissue engineering. Materials 2016, 9, 332. [CrossRef]

154. Abbasian, M.; Massoumi, B.; Mohammad-Rezaei, R.; Samadian, H.; Jaymand, M. Scaffolding polymeric biomaterials: Are naturally occurring biological macromolecules more appropriate for tissue engineering? Int. J. Biol. Macromol. 2019, 134, 673-694. [CrossRef]

155. Laschke, M.W.; Strohe, A.; Menger, M.D.; Alini, M.; Eglin, D. In vitro and in vivo evaluation of a novel nanosize hydroxyapatite particles/poly(ester-urethane) composite scaffold for bone tissue engineering. Acta Biomater. 2010, 6, 2020-2027. [CrossRef]

156. Lin, H.R.; Kuo, C.J.; Yang, C.Y.; Shaw, S.Y.; Wu, Y.J. Preparation of macroporous biodegradable PLGA scaffolds for cell attachment with the use of mixed salts as porogen additives. J. Biomed. Mater. Res. 2002, 63, 271-279. [CrossRef]

157. Eatemadi, A.; Daraee, H.; Zarghami, N.; Melat Yar, H.; Akbarzadeh, A. Nanofiber: Synthesis and biomedical applications. Artif. Cells Nanomed. Biotechnol. 2016, 44, 111-121. [CrossRef]

158. Farshi Azhar, F.; Olad, A.; Salehi, R. Fabrication and characterization of chitosan-gelatin/nanohydroxyapatitepolyaniline composite with potential application in tissue engineering scaffolds. Des. Monomers Polym. 2014, 17, 654-667. [CrossRef]

159. Guan, J.; Fujimoto, K.L.; Sacks, M.S.; Wagner, W.R. Preparation and characterization of highly porous, biodegradable polyurethane scaffolds for soft tissue applications. Biomaterials 2005, 26, 3961-3971. [CrossRef] [PubMed]

160. Thomson, R.C.; Wake, M.C.; Yaszemski, M.J.; Mikos, A.G. Biodegradable polymer scaffolds to regenerate organs. In Biopolymers II; Springer: Berlin/Heidelberg, Germany, 1995; pp. 245-274.

161. Pattanayak, D.K.; Fukuda, A.; Matsushita, T.; Takemoto, M.; Fujibayashi, S.; Sasaki, K.; Nishida, N.; Nakamura, T.; Kokubo, T. Bioactive Ti metal analogous to human cancellous bone: Fabrication by selective laser melting and chemical treatments. Acta Biomater. 2011, 7, 1398-1406. [CrossRef] [PubMed]

162. Eosoly, S.; Brabazon, D.; Lohfeld, S.; Looney, L. Selective laser sintering of hydroxyapatite/poly-epsiloncaprolactone scaffolds. Acta Biomater. 2010, 6, 2511-2517. [CrossRef] [PubMed]

163. Melchels, F.P.; Bertoldi, K.; Gabbrielli, R.; Velders, A.H.; Feijen, J.; Grijpma, D.W. Mathematically defined tissue engineering scaffold architectures prepared by stereolithography. Biomaterials 2010, 31, 6909-6916. [CrossRef] [PubMed]

164. Lam, C.X.F.; Mo, X.M.; Teoh, S.H.; Hutmacher, D.W. Scaffold development using 3D printing with a starch-based polymer. Mater. Sci. Eng. C 2002, 20,49-56. [CrossRef]

165. Raeisdasteh Hokmabad, V.; Davaran, S.; Ramazani, A.; Salehi, R. Design and fabrication of porous biodegradable scaffolds: A strategy for tissue engineering. J. Biomater. Sci. Polym. Ed. 2017, 28, 1797-1825. [CrossRef] [PubMed] 
166. dos Santos, K.S.; Coelho, J.F.; Ferreira, P.; Pinto, I.; Lorenzetti, S.G.; Ferreira, E.I.; Higa, O.Z.; Gil, M.H. Synthesis and characterization of membranes obtained by graft copolymerization of 2-hydroxyethyl methacrylate and acrylic acid onto chitosan. Int. J. Pharm. 2006, 310, 37-45. [CrossRef]

167. Asti, A.; Gioglio, L. Natural and synthetic biodegradable polymers: Different scaffolds for cell expansion and tissue formation. Int. J. Artif. Organs 2014, 37, 187-205. [CrossRef]

168. Sreejalekshmi, K.G.; Nair, P.D. Biomimeticity in tissue engineering scaffolds through synthetic peptide modifications-altering chemistry for enhanced biological response. J. Biomed. Mater. Res. A 2011, 96, 477-491. [CrossRef]

169. Cicuéndez, M.; Doadrio, J.C.; Hernández, A.; Portolés, M.T.; Izquierdo-Barba, I.; Vallet-Regí, M. Multifunctional $\mathrm{pH}$ sensitive 3D scaffolds for treatment and prevention of bone infection. Acta Biomater. 2018, 65, 450-461. [CrossRef]

170. O’Brien, F.J. Biomaterials \& scaffolds for tissue engineering. Mater. Today 2011, 14, 88-95. [CrossRef]

171. Mano, J.F.; Silva, G.A.; Azevedo, H.S.; Malafaya, P.B.; Sousa, R.A.; Silva, S.S.; Boesel, L.F.; Oliveira, J.M.; Santos, T.C.; Marques, A.P.; et al. Natural origin biodegradable systems in tissue engineering and regenerative medicine: Present status and some moving trends. J. R. Soc. Interface 2007, 4, 999-1030. [CrossRef] [PubMed]

172. Titorencu, I.; Albu, M.G.; Nemecz, M.; Jinga, V.V. Natural polymer-cell bioconstructs for bone tissue engineering. Curr. Stem Cell Res. Ther. 2017, 12, 165-174. [CrossRef] [PubMed]

173. Dang, J.M.; Leong, K.W. Natural polymers for gene delivery and tissue engineering. Adv. Drug Deliv. Rev. 2006, 58, 487-499. [CrossRef]

174. Khoshnevisan, K.; Maleki, H.; Samadian, H.; Shahsavari, S.; Sarrafzadeh, M.H.; Larijani, B.; Dorkoosh, F.A.; Haghpanah, V.; Khorramizadeh, M.R. Cellulose acetate electrospun nanofibers for drug delivery systems: Applications and recent advances. Carbohydr. Polym. 2018, 198, 131-141. [CrossRef]

175. Ghormade, V.; Pathan, E.K.; Deshpande, M.V. Can fungi compete with marine sources for chitosan production? Int. J. Biol. Macromol. 2017, 104, 1415-1421. [CrossRef]

176. Grifoll-Romero, L.; Pascual, S.; Aragunde, H.; Biarnés, X.; Planas, A. Chitin deacetylases: Structures, specificities, and biotech applications. Polymers 2018, 10, 352. [CrossRef]

177. Sultankulov, B.; Berillo, D.; Sultankulova, K.; Tokay, T.; Saparov, A. Progress in the development of chitosan-based biomaterials for tissue engineering and regenerative medicine. Biomolecules 2019, 9, 470. [CrossRef]

178. Saravanan, S.; Leena, R.S.; Selvamurugan, N. Chitosan based biocomposite scaffolds for bone tissue engineering. Int. J. Biol. Macromol. 2016, 93, 1354-1365. [CrossRef]

179. Donnaloja, F.; Jacchetti, E.; Soncini, M.; Raimondi, M.T. Natural and synthetic polymers for bone scaffolds optimization. Polymers 2020, 12, 905. [CrossRef]

180. Rastogi, P.; Kandasubramanian, B. Review of alginate-based hydrogel bioprinting for application in tissue engineering. Biofabrication 2019, 11, 042001. [CrossRef] [PubMed]

181. Sun, J.; Tan, H. Alginate-Based biomaterials for regenerative medicine applications. Materials 2013, 6, 1285-1309. [CrossRef]

182. Venkatesan, J.; Bhatnagar, I.; Manivasagan, P.; Kang, K.H.; Kim, S.K. Alginate composites for bone tissue engineering: A review. Int. J. Biol. Macromol. 2015, 72, 269-281. [CrossRef]

183. Stevens, M.M.; Qanadilo, H.F.; Langer, R.; Prasad Shastri, V. A rapid-curing alginate gel system: Utility in periosteum-derived cartilage tissue engineering. Biomaterials 2004, 25, 887-894. [CrossRef]

184. Kuo, C.K.; Ma, P.X. Ionically crosslinked alginate hydrogels as scaffolds for tissue engineering: Part 1. Structure, gelation rate and mechanical properties. Biomaterials 2001, 22, 511-521. [CrossRef]

185. Lee, K.Y.; Mooney, D.J. Alginate: Properties and biomedical applications. Prog. Polym. Sci. 2012, 37, $106-126$. [CrossRef]

186. Akkouch, A.; Yu, Y.; Ozbolat, I.T. Microfabrication of scaffold-free tissue strands for three-dimensional tissue engineering. Biofabrication 2015, 7. [CrossRef] [PubMed]

187. Yu, Y.; Ozbolat, I.T. Tissue strands as "bioink" for scale-up organ printing. In Proceedings of the 2014 36th Annual International Conference of the IEEE Engineering in Medicine and Biology Society, Chicago, IL, USA, 26 August 2014; Volume 2014, pp. 1428-1431. [CrossRef]

188. Wu, Y.; Hospodiuk, M.; Peng, W.; Gudapati, H.; Neuberger, T.; Koduru, S.; Ravnic, D.J.; Ozbolat, I.T. Porous tissue strands: Avascular building blocks for scalable tissue fabrication. Biofabrication 2018, 11. [CrossRef] [PubMed] 
189. Preethi Soundarya, S.; Haritha Menon, A.; Viji Chandran, S.; Selvamurugan, N. Bone tissue engineering: Scaffold preparation using chitosan and other biomaterials with different design and fabrication techniques. Int. J. Biol. Macromol. 2018, 119, 1228-1239. [CrossRef] [PubMed]

190. Knopf-Marques, H.; Pravda, M.; Wolfova, L.; Velebny, V.; Schaaf, P.; Vrana, N.E.; Lavalle, P. Hyaluronic acid and its derivatives in coating and delivery systems: Applications in tissue engineering, regenerative medicine and immunomodulation. Adv. Healthc. Mater. 2016, 5, 2841-2855. [CrossRef]

191. Zhu, Z.; Wang, Y.-M.; Yang, J.; Luo, X.-S. Hyaluronic acid: A versatile biomaterial in tissue engineering. Plast. Aesthetic Res. 2017, 4, 219-227. [CrossRef]

192. Zhao, N.; Wang, X.; Qin, L.; Zhai, M.; Yuan, J.; Chen, J.; Li, D. Effect of hyaluronic acid in bone formation and its applications in dentistry. J. Biomed. Mater. Res. A 2016, 104, 1560-1569. [CrossRef] [PubMed]

193. Deangelis, P.L.; Papaconstantinou, J.; Weigel, P.H. Isolation of a Streptococcus pyogenes gene locus that directs hyaluronan biosynthesis in acapsular mutants and in heterologous bacteria. J. Biol. Chem. 1993, 268, 14568-14571.

194. Stumpf, T.R.; Yang, X.; Zhang, J.; Cao, X. In situ and ex situ modifications of bacterial cellulose for applications in tissue engineering. Mater. Sci. Eng. C 2018, 82, 372-383. [CrossRef] [PubMed]

195. Khan, F.; Ahmad, S.R. Polysaccharides and their derivatives for versatile tissue engineering application. Macromol. Biosci. 2013, 13, 395-421. [CrossRef]

196. Luo, H.; Cha, R.; Li, J.; Hao, W.; Zhang, Y.; Zhou, F. Advances in tissue engineering of nanocellulose-based scaffolds: A review. Carbohydr. Polym. 2019, 224. [CrossRef]

197. Andrzej, F.; Maulik, D.S.; Ryan, A.H.; William, V.A. Designing recombinant collagens for biomedical applications. Curr. Tissue Eng. Discontin. 2016, 5, 73-84. [CrossRef]

198. Fratzl, P.; Misof, K.; Zizak, I.; Rapp, G.; Amenitsch, H.; Bernstorff, S. Fibrillar structure and mechanical properties of collagen. J. Struct. Biol. 1998, 122, 119-122. [CrossRef]

199. del Mercato, L.L.; Passione, L.G.; Izzo, D.; Rinaldi, R.; Sannino, A.; Gervaso, F. Design and characterization of microcapsules-integrated collagen matrixes as multifunctional three-dimensional scaffolds for soft tissue engineering. J. Mech. Behav. Biomed. Mater. 2016, 62, 209-221. [CrossRef]

200. Cen, L.; Liu, W.; Cui, L.; Zhang, W.; Cao, Y. Collagen tissue engineering: Development of novel biomaterials and applications. Pediatr. Res. 2008, 63, 492-496. [CrossRef]

201. Kutschka, I.; Chen, I.Y.; Kofidis, T.; Arai, T.; von Degenfeld, G.; Sheikh, A.Y.; Hendry, S.L.; Pearl, J.; Hoyt, G.; Sista, R.; et al. Collagen matrices enhance survival of transplanted cardiomyoblasts and contribute to functional improvement of ischemic rat hearts. Circulation 2006, 114, I167-I173. [CrossRef]

202. Zhang, D.; Wu, X.; Chen, J.; Lin, K. The development of collagen based composite scaffolds for bone regeneration. Bioact. Mater. 2018, 3, 129-138. [CrossRef]

203. Ferreira, A.M.; Gentile, P.; Chiono, V.; Ciardelli, G. Collagen for bone tissue regeneration. Acta Biomater. 2012, 8, 3191-3200. [CrossRef] [PubMed]

204. Meyer, M. Processing of collagen based biomaterials and the resulting materials properties. Biomed. Eng. Online 2019, 18, 24. [CrossRef]

205. Shoseyov, O.; Posen, Y.; Grynspan, F. Human collagen produced in plants: More than just another molecule. Bioengineered 2014, 5, 49-52. [CrossRef]

206. Bello, A.B.; Kim, D.; Kim, D.; Park, H.; Lee, S.-H. Engineering and functionalization of gelatin biomaterials: From cell culture to medical applications. Tissue Eng. Part B Rev. 2020, 26, 164-180. [CrossRef] [PubMed]

207. Oryan, A.; Alidadi, S.; Bigham-Sadegh, A.; Moshiri, A. Comparative study on the role of gelatin, chitosan and their combination as tissue engineered scaffolds on healing and regeneration of critical sized bone defects: An in vivo study. J. Mater. Sci. Mater. Med. 2016, 27, 155. [CrossRef]

208. Lai, J.Y. Biocompatibility of chemically cross-linked gelatin hydrogels for ophthalmic use. J. Mater. Sci Mater. Med. 2010, 21, 1899-1911. [CrossRef] [PubMed]

209. Stevens, K.R.; Einerson, N.J.; Burmania, J.A.; Kao, W.J. In vivo biocompatibility of gelatin-based hydrogels and interpenetrating networks. J. Biomater. Sci. Polym. Ed. 2002, 13, 1353-1366. [CrossRef]

210. Echave, M.C.; Saenz del Burgo, L.; Pedraz, J.L.; Orive, G. Gelatin as biomaterial for tissue engineering. Curr. Pharm. Des. 2017, 23, 3567-3584. [CrossRef]

211. Breen, A.; O'Brien, T.; Pandit, A. Fibrin as a delivery system for therapeutic drugs and biomolecules. Tissue Eng. Part B Rev. 2009, 15, 201-214. [CrossRef] 
212. Shiu, H.T.; Goss, B.; Lutton, C.; Crawford, R.; Xiao, Y. Formation of blood clot on biomaterial implants influences bone healing. Tissue Eng. Part B Rev. 2014, 20, 697-712. [CrossRef]

213. Barsotti, M.C.; Felice, F.; Balbarini, A.; Di Stefano, R. Fibrin as a scaffold for cardiac tissue engineering. Biotechnol. Appl. Biochem. 2011, 58, 301-310. [CrossRef]

214. Park, C.H.; Woo, K.M. Fibrin-Based biomaterial applications in tissue engineering and regenerative medicine. In Biomimetic Medical Materials: From Nanotechnology to 3D Bioprinting; Noh, I., Ed.; Springer: Singapore, 2018; pp. 253-261. [CrossRef]

215. Barsotti, M.C.; Magera, A.; Armani, C.; Chiellini, F.; Felice, F.; Dinucci, D.; Piras, A.M.; Minnocci, A.; Solaro, R.; Soldani, G.; et al. Fibrin acts as biomimetic niche inducing both differentiation and stem cell marker expression of early human endothelial progenitor cells. Cell Prolif. 2011, 44, 33-48. [CrossRef]

216. Noori, A.; Ashrafi, S.J.; Vaez-Ghaemi, R.; Hatamian-Zaremi, A.; Webster, T.J. A review of fibrin and fibrin composites for bone tissue engineering. Int. J. Nanomed. 2017, 12, 4937-4961. [CrossRef] [PubMed]

217. Anitua, E.; Nurden, P.; Prado, R.; Nurden, A.T.; Padilla, S. Autologous fibrin scaffolds: When platelet- and plasma-derived biomolecules meet fibrin. Biomaterials 2019, 192, 440-460. [CrossRef]

218. Bhattacharjee, P.; Kundu, B.; Naskar, D.; Kim, H.-W.; Maiti, T.K.; Bhattacharya, D.; Kundu, S.C. Silk scaffolds in bone tissue engineering: An overview. Acta Biomater. 2017, 63, 1-17. [CrossRef]

219. Yao, D.; Liu, H.; Fan, Y. Silk scaffolds for musculoskeletal tissue engineering. Exp. Biol. Med. 2016, 241, 238-245. [CrossRef]

220. Melke, J.; Midha, S.; Ghosh, S.; Ito, K.; Hofmann, S. Silk fibroin as biomaterial for bone tissue engineering. Acta Biomater. 2016, 31, 1-16. [CrossRef]

221. Peng, C.A.; Kozubowski, L.; Marcotte, W.R., Jr. Advances in plant-derived scaffold proteins. Front. Plant Sci. 2020, 11, 122. [CrossRef]

222. Ahn, S.; Chantre, C.O.; Gannon, A.R.; Lind, J.U.; Campbell, P.H.; Grevesse, T.; O'Connor, B.B.; Parker, K.K. Soy protein/cellulose nanofiber scaffolds mimicking skin extracellular matrix for enhanced wound healing. Adv. Healthc. Mater. 2018, 7, e1701175. [CrossRef] [PubMed]

223. Chien, K.B.; Shah, R.N. Novel soy protein scaffolds for tissue regeneration: Material characterization and interaction with human mesenchymal stem cells. Acta Biomater. 2012, 8, 694-703. [CrossRef] [PubMed]

224. Curt, S.; Subirade, M.; Rouabhia, M. Production and in vitro evaluation of soy protein-based biofilms as a support for human keratinocyte and fibroblast culture. Tissue Eng. Part A 2009, 15, 1223-1232. [CrossRef] [PubMed]

225. Barkay-Olami, H.; Zilberman, M. Novel porous soy protein-based blend structures for biomedical applications: Microstructure, mechanical, and physical properties. J. Biomed. Mater. Res. B Appl. Biomater. 2016, 104, 1109-1120. [CrossRef]

226. Benton, G.; Arnaoutova, I.; George, J.; Kleinman, H.K.; Koblinski, J. Matrigel: From discovery and ECM mimicry to assays and models for cancer research. Adv. Drug Deliv. Rev. 2014, 79-80, 3-18. [CrossRef]

227. Hughes, C.S.; Postovit, L.M.; Lajoie, G.A. Matrigel: A complex protein mixture required for optimal growth of cell culture. Proteomics 2010, 10, 1886-1890. [CrossRef]

228. Poincloux, R.; Collin, O.; Lizárraga, F.; Romao, M.; Debray, M.; Piel, M.; Chavrier, P. Contractility of the cell rear drives invasion of breast tumor cells in 3D Matrigel. Proc. Natl. Acad. Sci. USA 2011, 108, 1943-1948. [CrossRef]

229. Wong, C.C.; Gilkes, D.M.; Zhang, H.; Chen, J.; Wei, H.; Chaturvedi, P.; Fraley, S.I.; Wong, C.M.; Khoo, U.S.; $\mathrm{Ng}$, I.O.; et al. Hypoxia-inducible factor 1 is a master regulator of breast cancer metastatic niche formation. Proc. Natl. Acad. Sci. USA 2011, 108, 16369-16374. [CrossRef]

230. Vasanthan, V.; Fatehi Hassanabad, A.; Pattar, S.; Niklewski, P.; Wagner, K.; Fedak, P.W.M. Promoting cardiac regeneration and repair using acellular biomaterials. Front. Bioeng. Biotechnol. 2020, 8, 291. [CrossRef]

231. Pattar, S.S.; Fatehi Hassanabad, A.; Fedak, P.W.M. Acellular extracellular matrix bioscaffolds for cardiac repair and regeneration. Front. Cell Dev. Biol. 2019, 7, 63. [CrossRef]

232. Salzberg, C.A.; Ashikari, A.Y.; Berry, C.; Hunsicker, L.M. Acellular dermal matrix-assisted direct-to-implant breast reconstruction and capsular contracture: A 13-year experience. Plast. Reconstr. Surg. 2016, 138, 329-337. [CrossRef] [PubMed]

233. Blaudez, F.; Ivanovski, S.; Hamlet, S.; Vaquette, C. An overview of decellularisation techniques of native tissues and tissue engineered products for bone, ligament and tendon regeneration. Methods 2020, 171, $28-40$. [CrossRef] [PubMed] 
234. Saldin, L.T.; Cramer, M.C.; Velankar, S.S.; White, L.J.; Badylak, S.F. Extracellular matrix hydrogels from decellularized tissues: Structure and function. Acta Biomater. 2017, 49, 1-15. [CrossRef] [PubMed]

235. Copes, F.; Pien, N.; Van Vlierberghe, S.; Boccafoschi, F.; Mantovani, D. Collagen-based tissue engineering strategies for vascular medicine. Front. Bioeng. Biotechnol. 2019, 7, 166. [CrossRef] [PubMed]

236. Drury, J.L.; Mooney, D.J. Hydrogels for tissue engineering: Scaffold design variables and applications. Biomaterials 2003, 24, 4337-4351. [CrossRef]

237. Sathaye, S.; Mbi, A.; Sonmez, C.; Chen, Y.; Blair, D.L.; Schneider, J.P.; Pochan, D.J. Rheology of peptide- and protein-based physical hydrogels: Are everyday measurements just scratching the surface? Wiley Interdiscip. Rev. Nanomed. Nanobiotechnol. 2015, 7, 34-68. [CrossRef]

238. Nguyen, K.T.; West, J.L. Photopolymerizable hydrogels for tissue engineering applications. Biomaterials 2002, 23, 4307-4314. [CrossRef]

239. Van Vlierberghe, S.; Dubruel, P.; Schacht, E. Biopolymer-based hydrogels as scaffolds for tissue engineering applications: A review. Biomacromolecules 2011, 12, 1387-1408. [CrossRef]

240. Shin, H.; Quinten Ruhé, P.; Mikos, A.G.; Jansen, J.A. In vivo bone and soft tissue response to injectable, biodegradable oligo(poly(ethylene glycol) fumarate) hydrogels. Biomaterials 2003, 24, 3201-3211. [CrossRef]

241. Tibbitt, M.W.; Anseth, K.S. Hydrogels as extracellular matrix mimics for 3D cell culture. Biotechnol. Bioeng. 2009, 103, 655-663. [CrossRef]

242. Yang, J.M.; Olanrele, O.S.; Zhang, X.; Hsu, C.C. Fabrication of hydrogel materials for biomedical applications. Adv. Exp. Med. Biol. 2018, 1077, 197-224. [CrossRef] [PubMed]

243. Peppas, N.A.; Keys, K.B.; Torres-Lugo, M.; Lowman, A.M. Poly(ethylene glycol)-containing hydrogels in drug delivery. J. Control. Release 1999, 62, 81-87. [CrossRef]

244. Stock, U.A.; Nagashima, M.; Khalil, P.N.; Nollert, G.D.; Herden, T.; Sperling, J.S.; Moran, A.; Lien, J.; Martin, D.P.; Schoen, F.J.; et al. Tissue-engineered valved conduits in the pulmonary circulation. J. Thorac. Cardiovasc. Surg. 2000, 119, 732-740. [CrossRef]

245. Cha, C.; Oh, J.; Kim, K.; Qiu, Y.; Joh, M.; Shin, S.R.; Wang, X.; Camci-Unal, G.; Wan, K.T.; Liao, R.; et al. Microfluidics-assisted fabrication of gelatin-silica core-shell microgels for injectable tissue constructs. Biomacromolecules 2014, 15, 283-290. [CrossRef]

246. Ou, K.L.; Hosseinkhani, H. Development of 3D in vitro technology for medical applications. Int. J. Mol. Sci. 2014, 15, 17938-17962. [CrossRef]

247. Frantz, C.; Stewart, K.M.; Weaver, V.M. The extracellular matrix at a glance. J. Cell Sci. 2010, 123, 4195-4200. [CrossRef]

248. McKee, T.J.; Perlman, G.; Morris, M.; Komarova, S.V. Extracellular matrix composition of connective tissues: A systematic review and meta-analysis. Sci. Rep. 2019, 9, 10542. [CrossRef]

249. Knight, E.; Przyborski, S. Advances in 3D cell culture technologies enabling tissue-like structures to be created in vitro. J. Anat. 2015, 227, 746-756. [CrossRef]

250. Sutherland, R.M.; Inch, W.R.; McCredie, J.A.; Kruuv, J. A multi-component radiation survival curve using an in vitro tumour model. Int. J. Radiat. Biol. Relat. Stud. Phys. Chem. Med. 1970, 18, 491-495. [CrossRef]

251. Sutherland, R.M.; McCredie, J.A.; Inch, W.R. Growth of multicell spheroids in tissue culture as a model of nodular carcinomas. J. Natl. Cancer Inst. 1971, 46, 113-120.

252. Mehta, G.; Hsiao, A.Y.; Ingram, M.; Luker, G.D.; Takayama, S. Opportunities and challenges for use of tumor spheroids as models to test drug delivery and efficacy. J. Control. Release 2012, 164, 192-204. [CrossRef] [PubMed]

253. Wang, S.; Wang, X.; Boone, J.; Wie, J.; Yip, K.P.; Zhang, J.; Wang, L.; Liu, R. Application of hanging drop technique for kidney tissue culture. Kidney Blood Press Res. 2017, 42, 220-231. [CrossRef] [PubMed]

254. Frey, O.; Misun, P.M.; Fluri, D.A.; Hengstler, J.G.; Hierlemann, A. Reconfigurable microfluidic hanging drop network for multi-tissue interaction and analysis. Nat. Commun. 2014, 5, 4250. [CrossRef]

255. Kurosawa, H. Methods for inducing embryoid body formation: In vitro differentiation system of embryonic stem cells. J. Biosci. Bioeng. 2007, 103, 389-398. [CrossRef]

256. Thoma, C.R.; Zimmermann, M.; Agarkova, I.; Kelm, J.M.; Krek, W. 3D cell culture systems modeling tumor growth determinants in cancer target discovery. Adv. Drug Deliv. Rev. 2014, 69-70, 29-41. [CrossRef]

257. Kochanek, S.J.; Close, D.A.; Johnston, P.A. High content screening characterization of head and neck squamous cell carcinoma multicellular tumor spheroid cultures generated in 384-Well ultra-low attachment plates to screen for better cancer drug leads. Assay Drug Dev. Technol. 2019, 17, 17-36. [CrossRef] 
258. Kim, J.A.; Choi, J.H.; Kim, M.; Rhee, W.J.; Son, B.; Jung, H.K.; Park, T.H. High-throughput generation of spheroids using magnetic nanoparticles for three-dimensional cell culture. Biomaterials 2013, 34, 8555-8563. [CrossRef] [PubMed]

259. Lewis, N.S.; Lewis, E.E.; Mullin, M.; Wheadon,H.; Dalby, M.J.; Berry, C.C. Magnetically levitated mesenchymal stem cell spheroids cultured with a collagen gel maintain phenotype and quiescence. J. Tissue Eng. 2017, 8. [CrossRef] [PubMed]

260. Antoni, D.; Burckel, H.; Josset, E.; Noel, G. Three-dimensional cell culture: A breakthrough in vivo. Int. J. Mol. Sci. 2015, 16, 5517-5527. [CrossRef]

261. Rauh, J.; Milan, F.; Günther, K.P.; Stiehler, M. Bioreactor systems for bone tissue engineering. Tissue Eng. Part B Rev. 2011, 17, 263-280. [CrossRef]

262. Zhang, S.; Liu, P.; Chen, L.; Wang, Y.; Wang, Z.; Zhang, B. The effects of spheroid formation of adipose-derived stem cells in a microgravity bioreactor on stemness properties and therapeutic potential. Biomaterials 2015, 41, 15-25. [CrossRef] [PubMed]

263. Clevers, H. Modeling development and disease with organoids. Cell 2016, 165, 1586-1597. [CrossRef] [PubMed]

264. Eiraku, M.; Watanabe, K.; Matsuo-Takasaki, M.; Kawada, M.; Yonemura, S.; Matsumura, M.; Wataya, T.; Nishiyama, A.; Muguruma, K.; Sasai, Y. Self-organized formation of polarized cortical tissues from ESCs and its active manipulation by extrinsic signals. Cell Stem Cell 2008, 3, 519-532. [CrossRef]

265. Eiraku, M.; Takata, N.; Ishibashi, H.; Kawada, M.; Sakakura, E.; Okuda, S.; Sekiguchi, K.; Adachi, T.; Sasai, Y. Self-organizing optic-cup morphogenesis in three-dimensional culture. Nature 2011, 472, 51-56. [CrossRef]

266. McCracken, K.W.; Catá, E.M.; Crawford, C.M.; Sinagoga, K.L.; Schumacher, M.; Rockich, B.E.; Tsai, Y.H.; Mayhew, C.N.; Spence, J.R.; Zavros, Y.; et al. Modelling human development and disease in pluripotent stem-cell-derived gastric organoids. Nature 2014, 516, 400-404. [CrossRef]

267. Wong, A.P.; Bear, C.E.; Chin, S.; Pasceri, P.; Thompson, T.O.; Huan, L.J.; Ratjen, F.; Ellis, J.; Rossant, J. Directed differentiation of human pluripotent stem cells into mature airway epithelia expressing functional CFTR protein. Nat. Biotechnol. 2012, 30, 876-882. [CrossRef]

268. Kurmann, A.A.; Serra, M.; Hawkins, F.; Rankin, S.A.; Mori, M.; Astapova, I.; Ullas, S.; Lin, S.; Bilodeau, M.; Rossant, J.; et al. Regeneration of Thyroid function by transplantation of differentiated pluripotent stem cells. Cell Stem Cell 2015, 17, 527-542. [CrossRef]

269. Spence, J.R.; Mayhew, C.N.; Rankin, S.A.; Kuhar, M.F.; Vallance, J.E.; Tolle, K.; Hoskins, E.E.; Kalinichenko, V.V.; Wells, S.I.; Zorn, A.M.; et al. Directed differentiation of human pluripotent stem cells into intestinal tissue in vitro. Nature 2011, 470, 105-109. [CrossRef]

270. Takebe, T.; Zhang, R.R.; Koike, H.; Kimura, M.; Yoshizawa, E.; Enomura, M.; Koike, N.; Sekine, K.; Taniguchi, H. Generation of a vascularized and functional human liver from an iPSC-derived organ bud transplant. Nat. Protoc. 2014, 9, 396-409. [CrossRef] [PubMed]

271. Mae, S.I.; Shono, A.; Shiota, F.; Yasuno, T.; Kajiwara, M.; Gotoda-Nishimura, N.; Arai, S.; Sato-Otubo, A.; Toyoda, T.; Takahashi, K.; et al. Monitoring and robust induction of nephrogenic intermediate mesoderm from human pluripotent stem cells. Nat. Commun. 2013, 4, 1367. [CrossRef]

272. Osaki, T.; Sivathanu, V.; Kamm, R.D. Vascularized microfluidic organ-chips for drug screening, disease models and tissue engineering. Curr. Opin. Biotechnol. 2018, 52, 116-123. [CrossRef]

273. Ryu, N.E.; Lee, S.H.; Park, H. Spheroid culture system methods and applications for mesenchymal stem cells. Cells 2019, 8, 1620. [CrossRef]

274. Switzer, B.R.; Summer, G.K. Collagen synthesis in human skin fibroblasts: Effects of ascorbate, -ketoglutarate and ferrous ion on proline hydroxylation. J. Nutr. 1972, 102, 721-728. [CrossRef] [PubMed]

275. Hata, R.; Senoo, H. L-ascorbic acid 2-phosphate stimulates collagen accumulation, cell proliferation, and formation of a three-dimensional tissuelike substance by skin fibroblasts. J. Cell Physiol. 1989, 138, 8-16. [CrossRef]

276. Michel, M.; L'Heureux, N.; Pouliot, R.; Xu, W.; Auger, F.A.; Germain, L. Characterization of a new tissue-engineered human skin equivalent with hair. In Vitro Cell. Dev. Biol. Anim. 1999, 35, 318-326. [CrossRef] 
277. Germain, L.; Larouche, D.; Nedelec, B.; Perreault, I.; Duranceau, L.; Bortoluzzi, P.; Beaudoin Cloutier, C.; Genest, H.; Caouette-Laberge, L.; Dumas, A.; et al. Autologous bilayered self-assembled skin substitutes (SASSs) as permanent grafts: A case series of 14 severely burned patients indicating clinical effectiveness. Eur. Cells Mater. 2018, 36, 128-141. [CrossRef]

278. Cantin-Warren, L.; Guignard, R.; Cortez Ghio, S.; Larouche, D.; Auger, F.; Germain, L. Specialized living wound dressing based on the self-assembly approach of tissue engineering. J. Funct. Biomater. 2018, 9, 53. [CrossRef]

279. Proulx, S.; Uwamaliya, J.; Carrier, P.; Deschambeault, A.; Audet, C.; Giasson, C.; Guérin, S.; Auger, F.; Germain, L. Reconstruction of a human cornea by the self-assembly approach of tissue engineering using the three native cell types. Mol. Vis. 2010, 16, 2192-2201. [PubMed]

280. Bouhout, S.; Perron, E.; Gauvin, R.; Bernard, G.; Ouellet, G.; Cattan, V.; Bolduc, S. In vitro reconstruction of an autologous, watertight, and resistant vesical equivalent. Tissue Eng. Part A 2010, 16, 1539-1548. [CrossRef]

281. Bouhout, S.; Chabaud, S.; Bolduc, S. Organ-specific matrix self-assembled by mesenchymal cells improves the normal urothelial differentiation in vitro. World J. Urol. 2016, 34, 121-130. [CrossRef]

282. Magnan, M.; Lévesque, P.; Gauvin, R.; Dubé, J.; Barrieras, D.; El-Hakim, A.; Bolduc, S. Tissue engineering of a genitourinary tubular tissue graft resistant to suturing and high internal pressures. Tissue Eng. Part A 2009, 15, 197-202. [CrossRef] [PubMed]

283. Vallée, M.; Côté, J.F.; Fradette, J. Adipose-tissue engineering: Taking advantage of the properties of human adipose-derived stem/stromal cells. Pathol. Biol. 2009, 57, 309-317. [CrossRef] [PubMed]

284. Galbraith, T.; Clafshenkel, W.P.; Kawecki, F.; Blanckaert, C.; Labbé, B.; Fortin, M.; Auger, F.A.; Fradette, J. A cell-based self-assembly approach for the production of human osseous tissues from adipose-derived stromal/stem cells. Adv. Healthc. Mater. 2017, 6. [CrossRef]

285. Spiekman, M.; Van Dongen, J.A.; Willemsen, J.C.; Hoppe, D.L.; Van Der Lei, B.; Harmsen, M.C. The power of fat and its adipose-derived stromal cells: Emerging concepts for fibrotic scar treatment. J. Tissue Eng. Regen. Med. 2017, 11, 3220-3235. [CrossRef] [PubMed]

286. Vallières, K.; Laterreur, V.; Tondreau, M.Y.; Ruel, J.; Germain, L.; Fradette, J.; Auger, F.A. Human adipose-derived stromal cells for the production of completely autologous self-assembled tissue-engineered vascular substitutes. Acta Biomater. 2015, 24, 209-219. [CrossRef]

287. Rousseau, A.; Fradette, J.; Bernard, G.; Gauvin, R.; Laterreur, V.; Bolduc, S. Adipose-derived stromal cells for the reconstruction of a human vesical equivalent. J. Tissue Eng. Regen. Med. 2015, 9, E135-E143. [CrossRef]

288. Orabi, H.; Saba, I.; Rousseau, A.; Bolduc, S. Novel three-dimensional autologous tissue-engineered vaginal tissues using the self-assembly technique. Transl. Res. 2017, 180, 22-36. [CrossRef]

289. Simon, F.; Bergeron, D.; Larochelle, S.; Lopez-Valle, C.A.; Genest, H.; Armour, A.; Moulin, V.J. Enhanced secretion of TIMP-1 by human hypertrophic scar keratinocytes could contribute to fibrosis. Burn. J. Int. Soc. Burn Inj. 2012, 38, 421-427. [CrossRef]

290. Chabaud, S.; Corriveau, M.P.; Grodzicky, T.; Senecal, J.L.; Chartier, S.; Raymond, Y.; Moulin, V.J. Decreased secretion of MMP by non-lesional late-stage scleroderma fibroblasts after selection via activation of the apoptotic Fas-pathway. J. Cell Physiol. 2011, 226, 1907-1914. [CrossRef]

291. Corriveau, M.P.; Boufaied, I.; Lessard, J.; Chabaud, S.; Senecal, J.L.; Grodzicky, T.; Chartier, S.; Raymond, Y.; Moulin, V.J. The fibrotic phenotype of systemic sclerosis fibroblasts varies with disease duration and severity of skin involvement: Reconstitution of skin fibrosis development using a tissue engineering approach. J. Pathol. 2009, 217, 534-542. [CrossRef]

292. Bureau, M.; Pelletier, J.; Rousseau, A.; Bernard, G.; Chabaud, S.; Bolduc, S. Demonstration of the direct impact of ketamine on urothelium using a tissue engineered bladder model. Can. Urol. Assoc. J. L'Assoc. Urol. Can. 2015, 9, E613-E617. [CrossRef] [PubMed]

293. Esparza-López, J.; Martínez-Aguilar, J.F.; Ibarra-Sánchez, M.D.J. Deriving primary cancer cell cultures for personalized therapy. Rev. Investig. Clin. 2019, 71. [CrossRef]

294. Zhang, Z.; Guan, N.; Li, T.; Mais, D.E.; Wang, M. Quality control of cell-based high-throughput drug screening. Acta Pharm. Sin. B 2012, 2, 429-438. [CrossRef]

295. Szymański, P.; Markowicz, M.; Mikiciuk-Olasik, E. Adaptation of high-throughput screening in drug discovery-Toxicological screening tests. Int. J. Mol. Sci. 2011, 13, 427-452. [CrossRef]

296. McMillin, D.W.; Negri, J.M.; Mitsiades, C.S. The role of tumour-stromal interactions in modifying drug response: Challenges and opportunities. Nat. Rev. Drug Discov. 2013, 12, 217-228. [CrossRef] 
297. Lee, S.H.; Hu, W.; Matulay, J.T.; Silva, M.V.; Owczarek, T.B.; Kim, K.; Chua, C.W.; Barlow, L.J.; Kandoth, C.; Williams, A.B.; et al. Tumor evolution and drug response in patient-derived organoid models of bladder cancer. Cell 2018, 173, 515-528. [CrossRef]

298. van der Valk, J.; Bieback, K.; Buta, C.; Cochrane, B.; Dirks, W.G.; Fu, J.; Hickman, J.J.; Hohensee, C.; Kolar, R.; Liebsch, M.; et al. Fetal Bovine Serum (FBS): Past-Present-Future. ALTEX 2018, 35, 99-118. [CrossRef]

299. Volz, A.C.; Kluger, P.J. Completely serum-free and chemically defined adipocyte development and maintenance. Cytotherapy 2018, 20, 576-588. [CrossRef]

300. Faghih, H.; Javeri, A.; Amini, H.; Taha, M.F. Directed differentiation of human adipose tissue-derived stem cells to dopaminergic neurons in low-serum and serum-free conditions. Neurosci. Lett. 2019, 708. [CrossRef]

301. Pupovac, A.; Senturk, B.; Griffoni, C.; Maniura-Weber, K.; Rottmar, M.; McArthur, S.L. Toward immunocompetent 3D skin models. Adv. Healthc. Mater. 2018, 7, e1701405. [CrossRef]

302. Lorthois, I.; Simard, M.; Morin, S.; Pouliot, R. Infiltration of T cells into a three-dimensional psoriatic skin model mimics pathological key features. Int. J. Mol. Sci. 2019, 20, 1670. [CrossRef]

303. Maharjan, S.; Cecen, B.; Zhang, Y.S. 3D immunocompetent organ-on-a-chip models. Small Methods 2020, 21. [CrossRef]

304. L'Heureux, N.; Paquet, S.; Labbe, R.; Germain, L.; Auger, F.A. A completely biological tissue-engineered human blood vessel. FASEB J. 1998, 12, 47-56. [CrossRef]

305. Black, A.F.; Berthod, F.; L'Heureux, N.; Germain, L.; Auger, F.A. In vitro reconstruction of a human capillary-like network in a tissue-engineered skin equivalent. FASEB J. 1998, 12, 1331-1340. [CrossRef]

306. Gibot, L.; Galbraith, T.; Bourland, J.; Rogic, A.; Skobe, M.; Auger, F.A. Tissue-engineered 3D human lymphatic microvascular network for in vitro studies of lymphangiogenesis. Nat. Protoc. 2017, 12, 1077-1088. [CrossRef]

307. Imbeault, A.; Bernard, G.; Rousseau, A.; Morissette, A.; Chabaud, S.; Bouhout, S.; Bolduc, S. An endothelialized urothelial cell-seeded tubular graft for urethral replacement. Can. Urol. Assoc. J. L'Assoc. Urol. Can. 2013, 7, E4-E9. [CrossRef]

308. Chabaud, S.; Rousseau, A.; Marcoux, T.L.; Bolduc, S. Inexpensive production of near-native engineered stromas. J. Tissue Eng. Regen Med. 2017, 11, 1377-1389. [CrossRef]

309. Sekine, H.; Shimizu, T.; Sakaguchi, K.; Dobashi, I.; Wada, M.; Yamato, M.; Kobayashi, E.; Umezu, M.; Okano, T. In vitro fabrication of functional three-dimensional tissues with perfusable blood vessels. Nat. Commun. 2013, 4, 1399. [CrossRef]

310. Sarker, M.D.; Naghieh, S.; Sharma, N.K.; Chen, X. 3D biofabrication of vascular networks for tissue regeneration: A report on recent advances. J. Pharm. Anal. 2018, 8, 277-296. [CrossRef]

311. Sarker, M.; Chen, X.B.; Schreyer, D.J. Experimental approaches to vascularisation within tissue engineering constructs. J. Biomater. Sci. Polym. Ed. 2015, 26, 683-734. [CrossRef]

312. Salerno, A.; Cesarelli, G.; Pedram, P.; Netti, P.A. Modular strategies to build cell-free and cell-laden scaffolds towards bioengineered tissues and organs. J. Clin. Med. 2019, 8, 1816. [CrossRef] [PubMed]

313. Bai, J.; Wang, C. Organoids and microphysiological systems: New tools for ophthalmic drug discovery. Front. Pharmacol. 2020, 11, 407. [CrossRef] [PubMed]

314. Zhao, Z.; Vizetto-Duarte, C.; Moay, Z.K.; Setyawati, M.I.; Rakshit, M.; Kathawala, M.H.; Ng, K.W. Composite hydrogels in three-dimensional in vitro models. Front. Bioeng. Biotechnol. 2020, 8, 611. [CrossRef] [PubMed]

315. Kaarj, K.; Yoon, J.Y. Methods of delivering mechanical stimuli to organ-on-a-Chip. Micromachines 2019, 10, 700. [CrossRef] [PubMed]

316. Das, S.; Gordián-Vélez, W.J.; Ledebur, H.C.; Mourkioti, F.; Rompolas, P.; Chen, I.H.; Serruya, M.D.; Cullen, K.D. Innervation: The missing link for biofabricated tissues and organs. NPJ Regen. Med. 2020, 5, 11. [CrossRef] [PubMed]

317. Kryou, C.; Leva, V.; Chatzipetrou, M.; Zergioti, I. Bioprinting for liver transplantation. Bioengineering $2019,6,95$. [CrossRef]

318. Tang, H.; Abouleila, Y.; Si, L.; Ortega-Prieto, A.M.; Mummery, C.L.; Ingber, D.E.; Mashaghi, A. Human organs-on-chips for virology. Trends Microbiol. 2020. [CrossRef]

319. Santoso, J.W.; McCain, M.L. Neuromuscular disease modeling on a chip. Dis. Model. Mech. 2020, $13,044867$. [CrossRef]

320. Sahu, S.; Sharan, S.K. Translating embryogenesis to generate organoids: Novel approaches to personalized medicine. iScience 2020, 23, 101485. [CrossRef] 
321. Leva, V.; Chatzipetrou, M.; Alexopoulos, L.; Tzeranis, D.S.; Zergioti, I. Direct laser printing of liver cells on porous collagen scaffolds. JLMN J. Laser Micro Nanoeng. 2018, 13, $234-237$.

322. Faulkner-Jones, A.; Fyfe, C.; Cornelissen, D.J.; Gardner, J.; King, J.; Courtney, A.; Shu, W. Bioprinting of human pluripotent stem cells and their directed differentiation into hepatocyte-like cells for the generation of mini-livers in 3D. Biofabrication 2015, 7, 044102. [CrossRef] [PubMed]

323. Steinway, S.N.; Saleh, J.; Koo, B.K.; Delacour, D.; Kim, D.H. Human microphysiological models of intestinal tissue and gut microbiome. Front. Bioeng. Biotechnol. 2020, 8, 725. [CrossRef] [PubMed]

(C) 2020 by the authors. Licensee MDPI, Basel, Switzerland. This article is an open access article distributed under the terms and conditions of the Creative Commons Attribution (CC BY) license (http://creativecommons.org/licenses/by/4.0/). 